\title{
Prediction of Performance of a Novel Concept of Solar Photovoltaic-Thermal Panel and Heat Pipe Hybrid System
}

\author{
S. Sami \\ Research Center for renewable Energy Catholic University of Cuenca, Cuenca, Ecuador \\ TransPacific Energy, Inc, NV, USA, 89183
}

*Corresponding Author: S. Sami, Research Center for renewable Energy Catholic University of Cuenca, Cuenca, Ecuador and Transpacífic Energy, Inc, NV, USA, 89183

\begin{abstract}
A numerical model to predict the behavior of a novel concept of a hybrid system composed of photovoltaic-thermal solar panel and heat pipe is presented hereby. This model has been developed to assess the performance, and energy conversion process of the hybrid system as well as the individual efficiencies of this process to produce hot water and electricity. The two-dimensional heat transfer and fluid flow dynamic model was developed to describe the behavior of a hybrid system under different conditions, namely; solar irradiance, heat pipe conditions and different refrigerants. The model is based upon the dynamic mass and energy equations coupled with the heat transfer formulas, and thermodynamic properties of refrigerants as well as thermal material properties of the PV solar panel and heat pipes. Finally, the model's prediction has been validated and fairly compared with available experimental data.
\end{abstract}

Keywords: Numerical modeling, simulation, photovoltaic-thermal solar, heat pipe, refrigerants, hybrid system performance, model validation.

\section{INTRODUCTION}

As public concern for climate change and sustainable energy consumption has grown, energy efficiency is increasingly being considered as the lowest-cost available energy resource, with the least environmental impact. New PV technologies reported in the literature [1-33] have been shown to improve energy utilization and efficiency of solar PV, such as multi-junction cells, optical frequency shifting, and concentrated photovoltaic (CPV) systems, among others; however, are still quite expensive.

Heat pipes are becoming increasingly popular as passive heat transfer technologies due to their high efficiency when the appropriate refrigerants are used as working fluids. Heat pipes are currently used in widespread industrial applications, such as solar, nanoparticles, Rankine cycles, nuclear, thermoelectric modules and ceramics, in which heat pipe technologies offer many key advantages over conventional technologies.

In order to improve the solar photovoltaic's' (PV) efficiency a novel concept of combined photovoltaic-thermal solar panel hybrid system has been developed and implemented [3-12], where the PV cells of the solar PV panels are cooled by water flows. The excess thermal energy is generated and dissipated due to the intrinsic conversion efficiency limitation of the cell. The dissipated and excess thermal energy increases the cell temperature and in turn reduces the conversion efficiency of the cell. The excess thermal energy absorbed by the cold-water flow though the heat exchanger thermal panel underneath the PV's cell can be used for various domestic or industrial applications. Therefore, the net result is an enhancement of the combined photovoltaic-thermal efficiency of the hybrid system and consequently the PV solar panel.

Heat pipes are effective and passive heat transfer devices that are capable of transferring heat through with small temperature differences between the heat source and the heat sink. A heat pipe is normally made of a sealed copper pipe, vacuumed and filled with working fluid such as refrigerant that boil at low temperatures. The distinct sections of the heat pipes are; the evaporator section, the condenser section and the adiabatic section where no heat transfer between the refrigerant and heat source or heat sink takes place. Heat absorbed at the evaporator section of the pipe boils the working fluid 
inside the heat pipe and vaporizes with latent heat of vaporization. This vapor of the working fluid inside the heat pipe is condensed in the condenser section where it releases its latent heat of condensation. The condensate working fluid is then channeled back to the evaporator section due to gravity and internal wicks. Readers interested in the comprehensive discussions of the heat pipes heat transfer mechanisms are advised to consult references [1-3, 18, 20, and 24-28,33].

A novel heat-pipe photovoltaic/thermal system was designed and constructed by Pei et al. [18] to supply simultaneously electrical and thermal energy. The authors developed a dynamic model to predict the performances of the heat-pipe photovoltaic/thermal system. Experiments were also conducted to validate the numerical results obtained during the simulation. A comparison between simulation values and experimental results demonstrated that the model was able to yield satisfactory predictions.

Another transient mathematical model for the integrated HP-PV/T-PCM system presented by Sweidan et al. [26] and was used to predict its performance under solar conditions and phase change material, PCM, melting point. The model was validated and applied on a typical office space in the city of Beirut to obtain an optimal design using a derivative free genetic algorithm. The incremental system cost associated with a heat pipe and PCM tank was used in the optimization to obtain a design resulting in minimum annual auxiliary heating cost to meet the hot water demand while providing the electricity needs at a lower number of PV panels due to improved efficiency.

On the other hand, Liang et al. [12] presented a dynamic model for a novel solar heating system based on hybrid photovoltaic/thermal (PVT) and heat pipes technology. The TRNSYS simulation platform of the PVT cogeneration heating system has been implemented for predicting the system performance of PVT solar cogeneration heating system. The inlet and outlet temperatures, the electrical power output of PVT collector, heat consumption, outlet temperatures of auxiliary heat source and outlet temperatures of heat storage tank of PVT collector have been studied in this paper. The results of this investigation showed heat gain of heat collector system between 12 am and $6 \mathrm{pm}$ on the typical day when the auxiliary heat source is not turned on can meet the load demand. The entire heating season that uses the solar fraction of this solar heating system is $31.7 \%$, which is close to the design value of $30 \%$.

A model has been introduced by Naghavi [29] for the integration of heat pipe solar water heater system (HPSWH) with phase change material (PCM) to control the overheating of supplied water during the day and extend the operation time of the solar water heater system. The heat pipe position needs to be adjusted depending upon the amount of absorbed solar radiation energy. On the other hand, PCM was placed at the bottom of the solar absorber plate and heat pipe, to absorb and store extra gained thermal energy of the absorber plate which is not collected by the heat pipe. Approximate analytical solutions have been used to estimate the amount of absorbed solar energy and thermal behavior of supplying water. One-phase approximation solution is applied to estimate the thickness and stored energy of the PCM. The results of this research showed the feasibility of integration of PCM as a mechanism for improvement of the overall performance of the HPSWH system.

In particular, Endalew [9] in his master thesis studied the performance of heat pipe solar collector for water heating. Experimental results were validated using numerical modeling. Heat pipes filled with distilled water as working fluid, were used for experimental tests. Both natural and forced convective heat pipe condensing mechanisms were studied and their results were compared with conventional natural circulation solar water heating system. Cross flow and parallel flow heat exchanger were also tested in forced type heat pipe condensing mechanism. Experimental and numerical results showed good agreement. Heat pipe solar collectors outperformed conventional solar collector because of their efficient heat transport method. Forced convective heat exchanger was found to give higher efficiency compared to natural convective heat pipe condensing system.

A hybrid photovoltaic solar assisted loop heat pipe/heat pump (PV-SALHP/HP) water heater system has been developed and numerically studied by Dai et al. [3]. The system used in the study is the combination of loop heat pipe (LHP) mode and heat pump (HP) mode, and the two modes can be run separately or compositely according to the weather conditions. The performances of independent heat pump (HP) mode and hybrid loop heat pipe/heat pump (LHP/HP) mode were simulated and compared to experimental data. Simulation results showed that on typical sunny days in spring or autumn, using LHP/HP mode could save $40.6 \%$ power consumption than HP mode. 
Recently Sami [33] presented a numerical simulation model for a novel concept of a hybrid system composed of photovoltaic thermal solar panels and a heat pump. This model was developed to assess the performance and energy conversion efficiency of this novel concept system intended to produce domestic hot water and electricity. The model is a two-dimensional heat transfer and fluid flow dynamic one and was developed to describe the behavior of the hybrid system under different solar irradiance, heat pump boundary conditions with different refrigerants. The model was established after the dynamic equations for mass and energy coupled with the heat transfer formulas, and the thermodynamic properties of refrigerants as well as material properties. The model compared fairly to experimental data.

The modeling and simulation of a novel hybrid system of solar photovoltaic-thermal panel and heat pipes hybrid system is presented hereby in this paper. A schematic diagram of the photovoltaicthermal solar-heat pipes hybrid system under study is shown in Figure.1. This novel concept is intended to enhance the energy conversion efficiency of the PV-Thermal solar/heat pipe hybrid system through recovering the excess thermal energy dissipated during the energy conversion process of the solar PV panels to produce domestic hot water (DHW) and electricity. This consequently, enhances energy conversion efficiency of the solar photovoltaic and the hybrid system. The conceptual photovoltaic-thermal panel integrated heat pipes design was modeled and analyzed using two-dimensional dynamic model based upon the heat transfer and fluid flow conversion equations. The model was developed to describe the steady state and dynamic thermal behavior of a combined photovoltaic cell-thermal panel as well as the heat pipes hybrid system under different conditions; solar irradiances, material properties, ambient and fluid flow conditions, refrigerants contained in the heat pipes and excess thermal energy recovered by the panel as well as boundary conditions. The predicted results presented herein include the efficiency of energy conversion process of the hybrid system, PV cell characteristics, behavior of the heat pipes with different refrigerants and finally, the thermal energy recovered by the hybrid system panel and delivered for domestic and/or industrial use under different conditions.

\section{Mathematical Model}

The study presented herein is based partly on the concept reported by Yang et al. [1], and an extension of the modeling reported by Sami and Campoverde [27] where a flat plate solar collector is attached to a PV panel. The hybrid system in question is composed of the PV solar panel and Thermal solar tube collector as well as heat pipe and thermal tank as shown in Figure.1. In the hybrid system, thin parallel tubes are welded on the backside of photovoltaic panel for the circulation of the cooling fluid. The various flow tubes in contact with the PV solar panel are connected to a heat exchanger where the evaporator section of the heat pipe is placed. The water flows through the thermal solar collector copper pipes and carry the recovered excess heat away from the solar PV panel and the thermal panel as shown in Figure 1. However, the condenser section of the heat pipe is placed ina thermal tank where it supplies the demand for hot water.

A typical PV panels output is in DC current and connected to a load controller and batteries as well as an inverter for converting the DC current output into AC current for potential use in applications where $\mathrm{AC}$ is required. In the following sections, the energy conversion process, the enhancement of the efficiency of the hybrid system as well as the characteristics of solar PV/Thermal panel and heat pipe are presented and discussed under different conditions; operating temperatures, solar radiations and different refrigerants filled in the heat pipe.

\section{SOLAR PV MODEL}

The solar photovoltaic panel is constructed of various modules and each module is consisted of arrays and cells. The dynamic current output can be obtained as follows [13-15], [17, 33], and [27, 28];

$I_{P}=I_{L}-I_{o}\left[\exp \left(\frac{q\left(V+I_{P} R_{S}\right)}{A k T_{C}}-\frac{V+I_{P} R_{S}}{R_{s h}}\right)\right]$

$\mathrm{I}_{\mathrm{p}}$ : Output current of the PV module

$\mathrm{I}_{\mathrm{L}}$ : Light generated current per module

$\mathrm{I}_{0}$ : Reverse saturation current per module

International Journal of Modern Studies in Mechanical Engineering (IJMSME) 
V: Terminal voltage per module

$\mathrm{R}_{\mathrm{s}}$ : Diode series resistance per module

$\mathrm{R}_{\mathrm{sh}}$ : Diode shunt resistance per module

q: Electric charge

$\mathrm{k}$ : The Boltzmann constant

A: Diode ideality factor for the module

Where;

$I_{o}=B T^{3} c\left[\exp \left(-\frac{E_{g o}}{K T_{C}}\right)\right]$

And;

$I_{L}=P_{1} G\left[1-P_{2}\left(G-G_{r}\right)+P_{3}\left(T_{C}-T_{r}\right)\right]$

Where;

The PV cell temperature, Tc, and is influenced by various factors such as solar radiation, ambient conditions, and wind speed. It is well known that the cell temperature impacts the PV output current, performance and its time-variation can be determined from references [18-22]. The AC power of the inverter output $\mathrm{P}(\mathrm{t})$ is calculated using the inverter efficiency $\eta_{i n v}$, output voltage between phases, neutral $V_{f n}$, and for single-phase current, $I_{o}$ and the power factor, $\cos \varphi$ as follows;

$P(t)=\sqrt{3} \eta_{i n v} V_{f n} I_{o} \cos \varphi$

\section{PV Thermal Model}

The following thermal analysis is performed for a single PV cell; however, it is assumed that all PV cells behave the same; therefore, it canbe applied to the whole PV solar panel.

The heat absorbed by the PV solar cell can be calculated by the following [27, 33];

$Q_{\text {in }}=\alpha_{a b s} G S_{p}$

Where;

$\alpha_{\mathrm{abs}}:$ Overall absorption coefficient

G: Total Solar radiation incident on the PV module

$\mathrm{S}_{\mathrm{p}}$ : Total area of the PV module

Meanwhile, the PV cell Temperature is computed from the following heat balance $[27,28,33]$;

$m C_{p_{-} \bmod u l e} \frac{d T_{C}}{d t}=Q_{\text {in }}-Q_{\text {conv }}-Q_{\text {elect }}$

Where;

$\mathrm{T}_{\mathrm{C}}$ : PV Cell Temperature

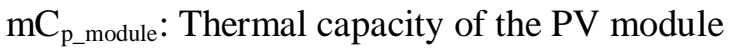

t: time

$\mathrm{Q}_{\text {in: }}$ : Energy received due to solar irradiation, equation (4)

$\mathrm{Q}_{\text {conv }}$ : Energy loss due to Convection

$\mathrm{Q}_{\text {elect: }}$ Electrical power generated

\subsection{Thermal Energy Incident in a PV Cell}

The thermal energy transferred from the PV cell to the Heat Transfer Fluid (HTF) as shown in Figure .1 , is determined from the heat balance across the PV cell and HTF in terms of the heat transfer mechanisms; conduction, convection and radiation as follows [27,28, 33];

The heat transfer by conduction is; 
$Q_{\text {conduction }}=\frac{K_{P v} \times \Delta T\left(T_{c}-T_{m}\right)}{L_{\text {cell }}}$

$\mathrm{T}_{\mathrm{m}}$ : Module Back-surface temperature

$\mathrm{K}_{\mathrm{Pv}}$ : Thermal conductivity of PV cell

$\mathrm{L}_{\text {cell }}$ : Length of a PV cell

The heat transfer by convection is determined from;

$Q_{\text {conduction }}=h_{\text {water }} \times \Delta T\left(T_{m}-T_{f}\right)$

$\mathrm{Q}_{\text {convection }}$ : Energy due to convection

$\mathrm{h}_{\text {water }}:$ Heat transfer coefficient

$\mathrm{T}_{\mathrm{f}}$ :Fluid temperature

And the heat transfer by radiation is;

$Q_{\text {conduction }}=\epsilon \times \sigma\left(T_{m}^{4}-T_{f}^{4}\right)$

$\mathrm{Q}_{\text {convection }}$ : Energy due to radiation

$\varepsilon$ : Emissivity PV cell

$\sigma:$ Stefan-Boltzmann constant

The finite difference formulation is used to determine the heat transfer fluid temperatures at each element where each heat transfer fluid tube is divided into number of thermal elements,

$T_{f}=T_{f_{-} i n}+\frac{\partial}{m_{\text {water }} C_{p}} \times t$

$\dot{\mathrm{m}}_{\mathrm{w}}$ : Water mass flow (HTF)

$\mathrm{C}_{\mathrm{p}}$ : Specific heat of water.

t: time

$\delta Q$ : the heat transfer per element

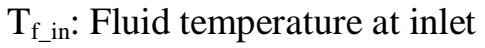

The thermal energy transferred from the back of the PV cell to the heat transfer fluid (HTF) is obtained by;

$Q_{\text {Thermal }}=m \times C_{p_{-} \text {water }} \times \Delta T\left(T_{f H x+1}-T_{f_{\text {In }}}\right)$

Where;

$\mathrm{Q}_{\text {Thermal: }}$ Energy from thermal process

$\mathrm{T}_{\mathrm{fHx}+1}$ : Fluid temperature at thermal element $(\mathrm{f}+1)$

$\mathrm{T}_{\mathrm{f}-\mathrm{i} n}$ : Fluid temperature at thermal element (1)

The total energy transferred to heat transfer fluid is calculated from the integration of equations (6) through (11) written for each element, $\mathrm{dx}$, along the length of each tube.

It is worthwhile mentioning that the PV cell and panel temperature is influenced by different factors and in particular the ambient conditions such as the temperature, humidity, wind speed among other parameters.

The back-temperature $\mathrm{T}_{\mathrm{m}}$ of the PV cell and PV panel can be calculated from the heat balance across the PV cellas follows [27, 33];

$Q_{i n}=m C_{p_{-} \bmod u l e} \Delta T=m C_{p_{-} \bmod u l e}\left(T_{C}-T_{m}\right)$

Where; $\mathrm{T}_{\mathrm{m}}$ is the module back-surface temperature.

It is assumed that the $T_{m}$ is equal to the surface temperature of the heat exchanger tubes welded to the solar PV cell/panel in close contact to the back surface of each of the PV cells. The heat transferred 
from the back of the PV cell to the heat transfer fluid (HTF)flowing in the heat exchanger tubes as shown in Figure, 1 is computed by the following forced heat transfer convection relationship [16,17, 33];

$Q_{\text {in }}=\pi D L h_{\text {water }} \Delta T=\pi D L h_{\text {water }}\left(T_{m}-T_{f}\right)$

Where;

D:Pipe diameter

L:Pipe length

$\mathrm{h}_{\text {water }}:$ Forced convection heat transfer coefficient

$\mathrm{T}_{\mathrm{f}}$ :Fluid temperature

Where the heat transfer coefficient, $\mathrm{h}_{\mathrm{water}}$ is approximated as [27];

$h w=\frac{K_{w}}{D_{H}} b_{2} R e^{n}$

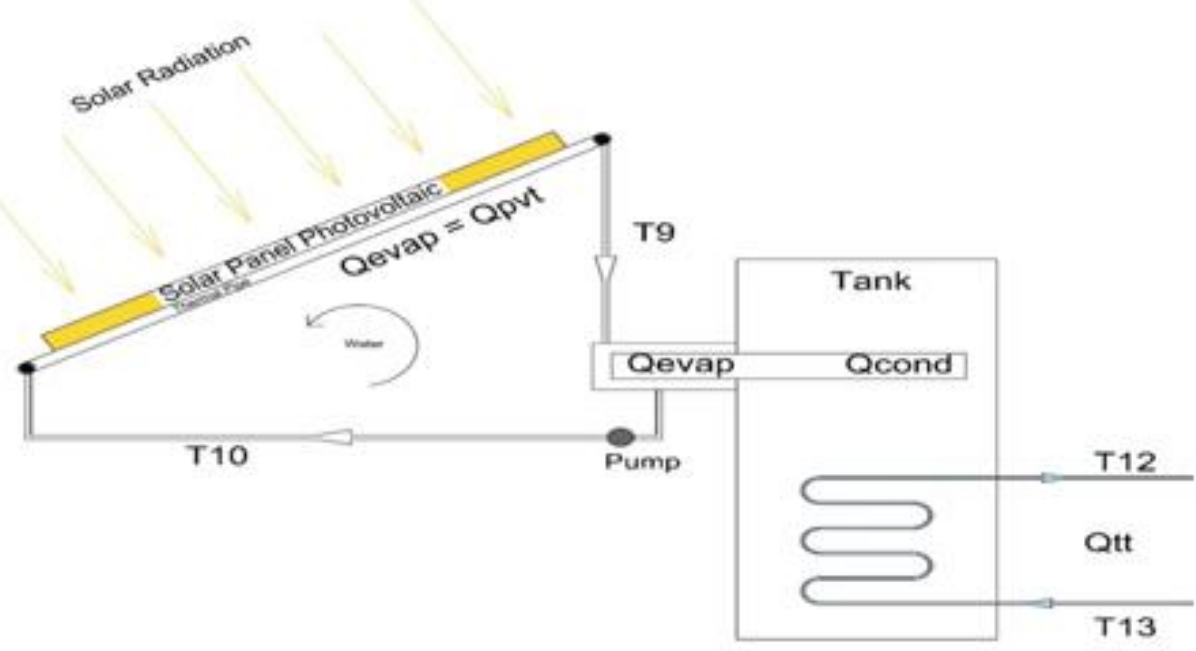

Figure1. PV/Thermal-Heat Pipe hybrid system

Where Re; is the Reynolds Number and $\mathrm{K}_{\mathrm{w}}$ represents thermal conductivity of water, $\mathrm{b}_{2}$ and $\mathrm{n}$ are numerical constants

Furthermore, to calculate the heat transfer fluid flow rate, circulating in the heat exchanger tubes, the following equation is usedcoupled with equations (13) and (14);

$Q_{\text {in }}=\dot{\mathrm{m}}_{\mathrm{w}} C_{p_{-} \text {water }}\left(T_{f+1}-T_{f}\right)$

$\dot{\mathrm{m}}_{\mathrm{w}}$ represents the water flow rate and;

$\mathrm{T}_{\mathrm{f}+1}$ : Water temperature at the next element.

$\mathrm{C}_{\mathrm{p}}$ : Specific heat of HTF.

The total thermal heat transferred to the HTF is obtained after equations (11) through (15);

$Q_{\text {th }}=\left(m_{\text {dot }} * n_{\text {pipe }}\right) *\left(T_{\text {sco }}-T_{\text {sco }}\right) * C p_{w} * \eta$

Where,

$m_{d o t}$ : Mass flow rate per pipe the heat exchanger tubes welded to the solar PV cell/panel in close contact to the back surface of each of the PV cells.

$n_{\text {pipe }}$ : Number of tubes of the heat exchanger welded to the solar PV panel.

$T_{s c o}, T_{s c o}$ : represent the outlet temperature of the solar collector and the inlet temperature to the solar collector, respectively.

$\eta$ : Heat exchanger efficiency. 
The thermal heat calculated by equation (16) is fed to the heat exchanger where the evaporator section of the heat pipe is placed as shown in Figure.1.This thermal heat is absorbed by the refrigerant filled in the evaporator section of the heat pipe and therefore, transmitted by natural circulation of the refrigerant to the condenser section of the heat pipe placed in the thermal tank where the heat of condensation is released to the water.

\section{HEAT PIPE MODEL}

To design a heat pipeand attain the required thermal capacity, the characteristic of the working fluid, the wick and the container must be determined. In order for the heat pipe to work properly, the pressure drop in the fluid flow has to be compensated by the pumping pressure in the wick and the capillarity as prescribed by Tardy and Sami [20,25], Endalew [9] and Reay and Kew [23];

$\Delta \mathrm{Pp}=\Delta \mathrm{Pi}+\Delta \mathrm{Pv}+\Delta \mathrm{Pg}$

Where $\Delta \mathrm{Pp}, \Delta \mathrm{Pl}, \Delta \mathrm{Pv}$ and $\Delta \mathrm{Pg}$ are the total pumping pressure, pressure drop for liquid return from condenser, pressure drop for vapor flow in the evaporator and gravity head, respectively.

The heat transfer limit for heat pipe depends on the construction of the heat pipe and the operating environment. The thermophysical properties of the working fluid used and the wick properties determine the design of the heat pipe.The physical phenomena that limit heat pipe heat transfer capillary, sonic, entrainment, boiling, frozen start up, continuum vapor, vapor pressure and condenser effects determine the lowest limit of these phenomena and are considered as a design limit. The main design limitations were extensively discussed in Tardy and Sami (2009), Faragaliet al. (2008); and Reay and Kew (2006) and Tardy and Sami (2008). Interested readers in the capillary, sonic, entrainment limit and boiling limits of the heat pipes are advised to consult the aforementioned references.

The design of heat pipe depends upon the selection of working fluids. In selection of the working fluid a number of factors are considered. In particular, the working fluid temperature range is an important criterion to be fulfilled. Refrigerants and refrigerant mixtures are widely used as working fluid for low temperature heat pipes applications because of lower vapor pressure and boiling points.

In solar application, the energy conversion and efficiency of heat transfer from the evaporator side of the heat pipe to condenser side becomes one of the important selection criteria for the working fluid in these particular applications. Hence, the use of working fluid with higher latent heat is beneficial to the application of the heat pipes. Water and different refrigerants such as R-134a, R-123, R-32, R$125, \mathrm{R}-152 \mathrm{a}, \mathrm{R}-1234 \mathrm{ze}$, and R-1234fz are considered in this investigation as working fluids inside heat pipe to study the impact of working fluids on the behavior of heat pipes as well as the hybrid system under investigation.

Natural convective heat transfer heat pipe using two-phase thermosyphon principals have been reported in the literature and studied by Endalew [2011] in water heating applications. On the other hand, Reference [9] also discussed the Forced convective condensers under either cross flow or parallel flow pattern. In the current study of the system shown in Figure .1, the two- phase thermosyphon condition exists where the condenser section of the heat pipe is directly inserted to the storage thermal tank. Therefore, it is assumed that natural convective heat transfer takes place and consequently the natural convection heat transfer mechanisms in the thermal tank is considered in this study. It was also assumed that the condensing water flow in the thermal tank is stagnant, and no temperature gradient along the axis of heat pipe.

The following gives the energy balance under natural convection heat transfer in the thermal tank for a single-control volume of heat pipe submerged in the thermal tank [9];

$V_{w} P_{w} C_{w} \frac{d T w}{d t}=\pi d o I_{\text {cond }} h_{e f f}\left(T_{h p}-T_{w}\right)-U_{\text {tan }} A_{\text {tan }}\left(T_{h p}-T_{a}\right)$

Where $\mathrm{V}_{\mathrm{w}}$ represents the water volume in the thermal tank and $\mathrm{U}_{\tan } \mathrm{A}_{\mathrm{tan}}$ is the overall heat transfer coefficient in the thermal tank and the equivalent area in the tank, respectively.

In addition, $T_{h p}, T_{w} T_{a}$ are the temperatures of heat pipe, water, and ambient air, respectively.

On the other hand, the effective heat transfer coefficient $h_{\text {eff }}$ of the condenser section of the heat pipe can be given by the following, Endalew (2011), 
$h_{e f f}=\left(\frac{1}{h_{\text {cond }}}+\frac{1}{h_{f}}+\frac{\delta_{h p}}{\kappa_{h p}}\right)$

Where, $\mathrm{h}_{\mathrm{f}}$ is the natural heat transfer coefficient between the water and the condenser in the thermal $\operatorname{tank}, \delta_{h p}$ represents the thickness of the heat pipe material, and $\kappa_{h p}$ is the thermal conductivity of the working fluid in the heat pipe.

In addition, $\mathrm{h}_{\text {cond }}$ represents the film condensation heat transfer coefficient and can be obtained from the following correlation suggested by references [22] and [9] and using the Nusselt equation;

$h_{\text {cond }}=0.729\left(\frac{\kappa_{l}^{3} \lambda \rho_{l}\left(\rho_{l}-\rho_{r}\right) g \sin \beta}{\mu_{l} d_{i}\left(T_{h p}-T_{w}\right)}\right)^{\frac{1}{4}}$

Where, $T_{h p}, T_{w}$, represent the temperatures of the heat pipe and the water in the tank respectively and $\rho_{l}, \rho_{r}$ are the liquid and vapor densities of the working fluid inside the heat pipe, respectively. And, $\mu_{l,}, d_{i}$ are the viscosity and internal diameter of the heat pipe, respectively.

In addition, the following equation gives the natural heat transfer coefficient $h_{f}$ between the water in the thermal tank to be heated and the condenser section of the heat pipe,and can also be developed using Nusselt equation; [22, 9];

$\frac{h_{f} d_{o}}{\kappa_{l}}=1.09\left(\frac{d_{o}^{3} \rho_{l}^{2} g \gamma\left(T_{h p}-T_{w}\right) C p}{\mu_{l} \kappa_{l}}\right)^{\frac{1}{5}}$

Where, $d_{o}$ represents the outside diameter of the condenser section of the heat pipe and Cpis the specific heat of the working fluid inside the heat pipe. And $\gamma$ is the specific heat ratio. $\mu_{l}$ represents the liquid viscosity of the working fluid.

In the following the energy and mass balance equations for the condenser section of the heat pipes are considered;

$Q_{\text {cond } h p}=h_{\text {eff }} *\left(T_{h p}-T_{w}\right) * d_{o} * I o * \pi$

Where, Io is the length of the condenser section of the heat pipe.

And,

$Q_{\text {evap } h p}=Q_{t h} * \eta$

On the other hand, the thermal energy drawn from the thermal tank and delivered for domestic or industrial use is;

$Q_{t t}=\eta_{h x} * m_{w Q t t} * C p_{w} *\left(T_{12}-T_{13}\right)$

Where, the $\mathrm{m}_{\mathrm{wQtt}}$ represents the water mass flow rate circulating between the thermal tank and the user application in question. $\mathrm{T}_{12}$ and $\mathrm{T}_{13}$ are the supply and return temperatures from the user application, respectively. $\eta_{h x}$ is the thermal tank efficiency.

The water mass flow rate for supplying hot water to the user's application is;

$m_{w_{Q t t}}=\frac{Q_{t t}}{\eta_{h x} * C p_{w} *\left(T_{12}-T_{13}\right)}$

The efficiency of the solar PV panels can be expressed as follows;

$\eta_{p v}=\frac{Q_{\text {elec }}}{Q_{\text {colector }}}$

Where, $Q_{\text {elec }}$ is calcualted by equation (4) and,

$Q_{\text {colector }}$ is obtained by equation (5).

The thermal efficiency of thermal energy transferred to the evaporator section of the heat pipe is;

$\eta_{Q t h}=\frac{Q_{t h}}{Q_{\text {colector }}}$

Where $Q_{t h}$ is calcualted by equation (16).

The thermal efficiency of the heat pipe can be obtained by the following equation; 
$\eta_{h p}=\frac{Q_{\text {cond } h p}}{Q_{\text {evap } h p}}$

Where, $Q_{\text {cond } h p}$ represents the heat released by the condenser section of the heat pipe and $Q_{\text {evap } h p}=Q_{t h} * \eta$ where $Q_{t h}$ calcualted by equation (16) is and $\eta$ is the thermal efficiency of the heat exchanger where the evaporator section of the heat pipe is placed.

Finally, the hybrid system energy conversion efficiency for harnessing energy from solar energy using of photovoltaic-thermal solar panel and heat pipe can be formulated as;

$\eta_{\text {sh }}=\frac{Q_{\text {cond } h p}+Q_{\text {elec }}}{Q_{\text {colector }}}$

Where, $Q_{\text {elec }}$ is calcualted by equation (4).

\section{Numerical Procedure}

The energy conversion and heat transfer mechanisms taking place during various processes; solar PVThermal and heat pipe as well as thermal tank as shown in Figure.1, are described in Equations (1) through (29). The model presented hereby is based on mass and energy balances of the individual components of the PV/T hybrid system; PV cell and the heat transfer fluid flowing in thermal tubes welded in the back of the PV panel and driving the heat pipe. This model permits to calculate the electrical power output of the solar PV panel, thermal energy recovered from the solar PV panel and supplied to the heat pipe, and thermal characteristics of the water flow driving the heat pipe, and thermodynamic and thermo physical properties of the refrigerants in the heat pipe and finally, the hybrid system total characteristics and individual efficiencies in terms of solar radiation and other geometrical parameters and boundary conditions.

These equations presented in (1) through (29) have been solved as per the logical flow diagram presented in Figures 2, where, the input parameters of the solar PV-thermal conditions such as solar radiation, ambient temperature and humidity as well as other independent and geometrical parameters for the solar thermal tubes geometries and heat pipe characteristics are defined. Dependent parameters were calculated and integrated in the finite-difference formulations. Iterations were performed until a converged solution is reached with acceptable iteration error.

The numerical procedure starts with the solar radiation, ambient conditions to calculate the solar PV cell temperature, and PV cell back temperature as well as heat transfer fluid mass flow characteristics circulating in the thermal closed loop at specified conditions. The thermodynamic and thermo physical properties of Heat Transfer Fluid (HTF) were employed to calculate the water flow rate. This follows by the finite-difference formulations to predict the time variation of the PV cell temperature, the PV back temperature, and thermal heat transferred to the Heat Transfer Fluid, Heat transfer fluid outlet temperature at the heat exchanger as well as the water temperature in the thermal tank and the heat transfer fluid that drives the evaporator section of the heat pipe. This step is followed by the selection of the heat pipe working fluids; refrigerant and refrigerant mixture, operating conditions, thermodynamic and thermo physical properties of the refrigerant circulating in the heat pipe. Finally, other hybrid system characteristics such as the thermal and power outputs and individual efficiencies are calculated as well as the hybrid system efficiency at each input condition.

The thermo physical and thermodynamic properties of the refrigerants considered in this study used in the aforementioned model and needed to close the system of equations are determined using REFPROP software as per reference [31]. The NIST REFPROP database [31] provides the most accurate thermo physical property models for a variety of industrially important working fluids and fluid mixtures, including the accepted standards ones. It has proven to be an extremely useful and accurate tool in calculating the thermo physical and thermodynamic properties of the refrigerants such as pressure, temperature, and enthalpy as well as others.

\section{RESULTS AND DISCUSSION}

In order to solve the aforementioned equations (1) through (29) and taking into account the heat and mass transfer mechanisms during the solar PV/thermal and heat pipe energy conversion processes, the above-mentioned equations were coded, integrated using the finite-difference formulations and solved as per logical flow chart depicted in Figure.2. In addition, for the purpose of validation, the predicted simulated results for PV solar panel were compared to data available. 
In the following sections, we present analysis and discussion of the numerical results predicted as well as validations of the proposed simulation model. The simulations were performed for at different temperature differences across the heat exchanger flow pipes bonded to the back of the solar PV panel. However, only results will be presented and analyzed for the temperature difference of $15{ }^{\circ} \mathrm{C}$ across the thermal tube. It is worthwhile noting that the numerical simulation presented hereby was conducted under different conditions such as; $\mathrm{PV}$ cell temperatures from $10^{\circ} \mathrm{C}$ through $70^{\circ} \mathrm{C}$, ambient temperatures from $10^{\circ} \mathrm{C}$ through $38^{\circ} \mathrm{C}$ and solarradiations;550, 750, 1000and $1200 \mathrm{w} / \mathrm{m}^{2}$ as well as different refrigerants filled in the heat pipe with lower Global Warming Potential (GWP) such as R134a (HFC 134a), R123 (HCFC 123), R125 (HFC 125), R32 (HFC32), R152a (HFC152a), R1234ze ( HFO 1234ze),R1234fz( (HFO 1234zf). Thermodynamic and thermo physical properties were obtained using the methodology outlined and presented in reference [31].

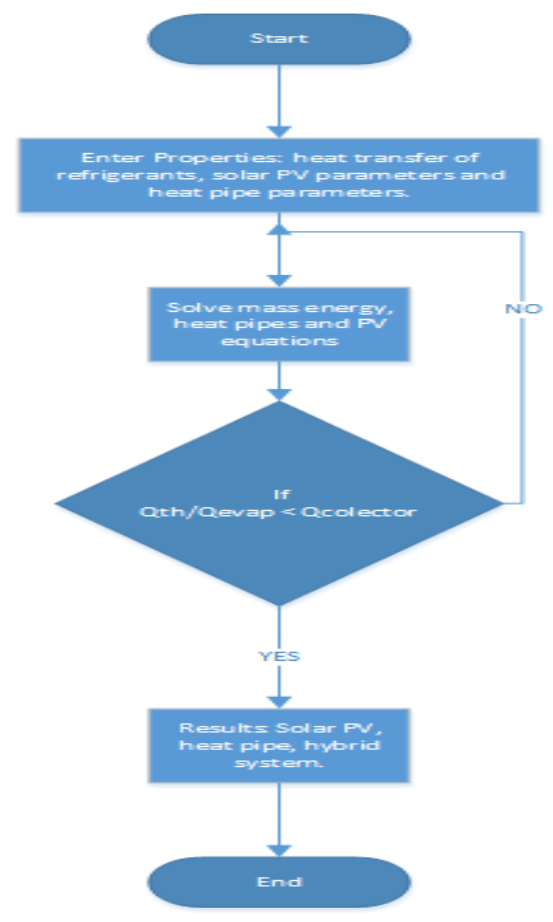

Figure2. Logical flow diagram

Figures 3 and 4 present a typical ambient temperature and solar isolation profiles at the site for various months of the year 2018 at different hours of the day. It is quite apparent that the peak solar irradiation and maximum temperatures occur at midday. However, average solar irradiation and ambient temperatures were used in the modeling and simulation of the Photovoltaic panels. The recording of the ambient conditions presented in Figure.4 during the same period showed that the relative humidity is stable during the various hours of the day.

Therefore, in the simulation of the PV thermal solar panel relative humilities were assumed constant. The PV characteristic curves are given in the manufacturer's specification sheet. The PV panel characteristic curves under consideration in this study are obtained from Faragali et al. [17]. Among the parameters used in this study are; Total surface area of the PV module (SP) is $0.617 \mathrm{~m} 2$, Total surface area of cells in module ( $\mathrm{Sc}$ ) is $0.5625 \mathrm{~m} 2$, module efficiency $12 \%$ at reference temperature $(298 \mathrm{~K})$, overall absorption coefficient is 0.73 , and Temperature coefficient is $0.0045 \mathrm{~K}-1$. Interested readers in the full range values of the other parameters are advised to consult Faragali et al. [17].

It is also assumed in this simulation that the whole panel is covered in PV cells, with no packing material that is used to fill in gaps between the cells on a panel. The PV cells are commercial grade mono crystalline silicon cells with electrical efficiency of $12 \%$, and have a thermal coefficient, of $0.54 \%[1 / \mathrm{K}]$, however, it is depending upon the rated solar radiation [21]. The thermal coefficient represents the degradation of PV cell output per degree of temperature increase. The heat exchanger pipes are bonded to the back of the PV solar model without any air gap to ensure complete heat transfer by conduction, convection and radiation to the fluid flowing in the thermal pipes. The exiting temperatures of heat transfer fluid vary between $25 \mathrm{C}^{\circ}$ to $75{ }^{\circ} \mathrm{C}$. This heat transfer fluid drives the 
evaporator section of the heat pipe and the thermal heat absorbed from the heat transfer fluid evaporates the refrigerant in the evaporator section of the heat pipe. The vapor refrigerant is then circulated by natural convection and carried to the condenser section of the heat pipe where it dissipates its heat of condensation to the water in the thermal tank.

As per equations (6) through (14), an increase in the PV cell temperature will result in an increase in the back-cell temperature and consequently the fluid temperature due to the heat transfer from solar energy by conduction and convection as well as radiation, respectively.

Consequently, this increases the thermal heat driving the evaporator section of the heat pipe and increases the thermal energy transferred to the thermal tank.

Furthermore, Figures 5 through 7show the dynamic behavior of the three important and critical temperatures in this analysis; PV cell, PV back and fluid temperatures at different solar radiations. These figures clearly support the aforementioned statement that the higher the cell temperature the higher the PV back cell and higher fluid temperatures as well as the thermal energy delivered to the evaporator section of the heat pipe. It is quite evident from the results presented in these figures that the cell temperatures increase with the increase of solar radiation. This can be interpreted as per equations (1) and (2), where the higher the solar radiations the higher the energy absorbed by the PV cell and consequently the higher the temperature of the PV cell until reaches the design temperature.

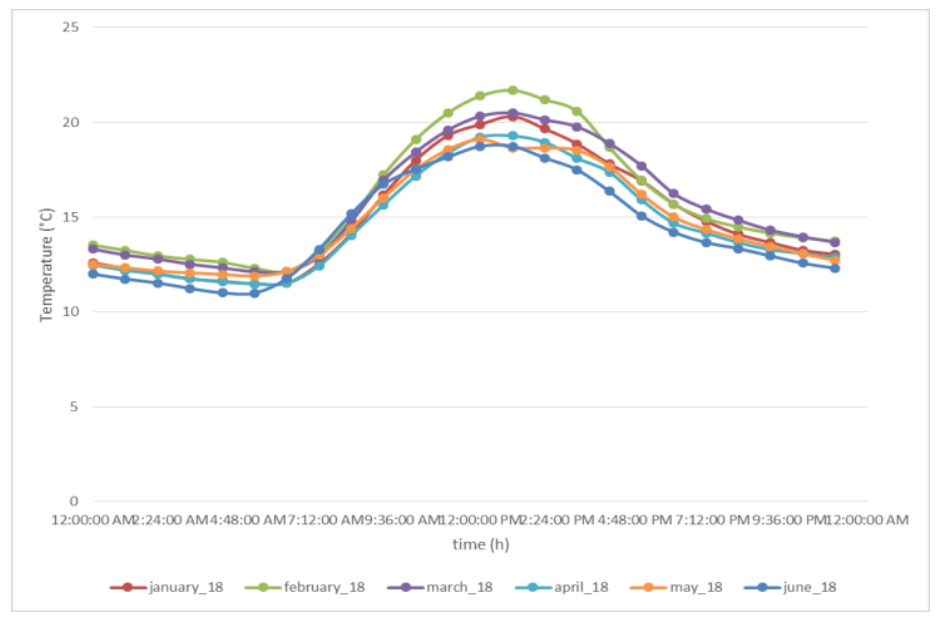

Figure3. Ambienttemperatures $\left({ }^{\circ} \mathrm{C}\right)$ profile 2018

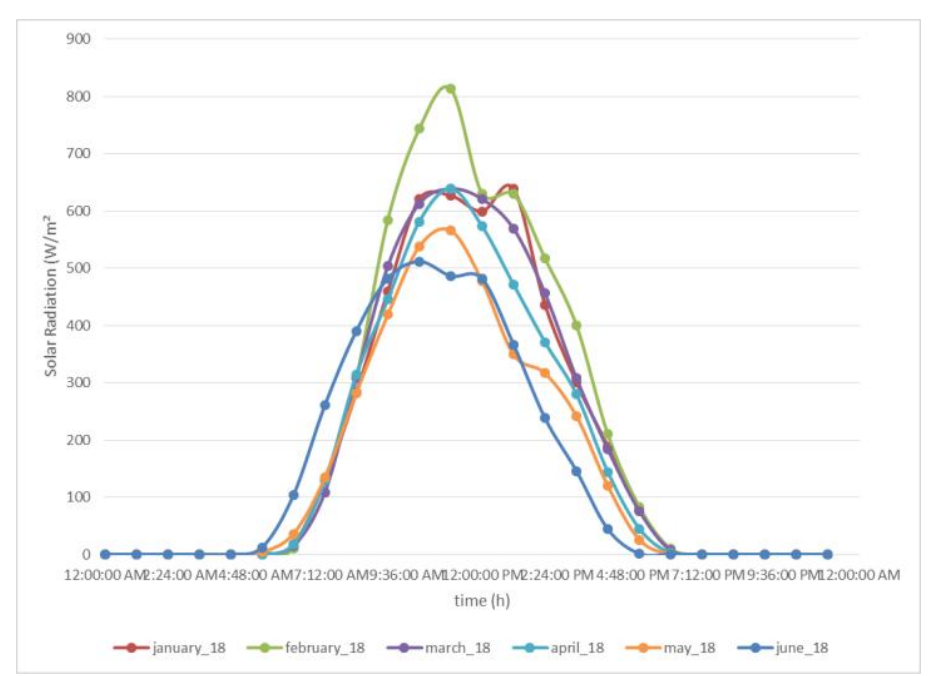

Figure4. Solar irradiances $\left(w / m^{2}\right)$ Profile 2018

However, it is important to note that the changes in the PV cell temperature caused by solar radiation have a dynamic nature as demonstrated in Figure.5. The PV panel heats up and cools down gradually depending upon the changes in solar radiation in a dynamic response and consequently the power output from the PV panel. This has been reported and discussed in the literature where similar observations were presented in references $[12,15,30]$. 
Figure.8 presents the thermal heat released from one solar PV panel at different solar radiations and heat pipe temperatures. It is worthwhile mentioning that two heat pipes were used in the simulation to satisfy the energy balance. The heat pipe temperature is the temperature where heat pipe's evaporation and condensation of the working fluid taking place.In this study, the working fluids filled in the heat pipe were water and the aforementioned refrigerants. The heat balance performed at the hybrid system presented in Figure.1, suggested that two heat pipes result in an optimized performance of the system in question. The results presented in this figure for water as working fluid show that the higher the solar radiations the higher the thermal energy absorbed by the heat transfer fluid. In addition, at a specific solar radiation, the higher the thermal heat transferred to the heat transfer fluid and the evaporator section of the heat pipe the higher the heat pipe temperature.

The Efficiency of thermal Heat released calculated by equation (27) at different solar radiations and heat transfer fluid temperatures for one solar PV panel with two heat pipes filled with water is presented in Figure.9. The thermal heat efficiency is defined as the heat transferred divided by the solar radiation absorbed by the PV panel. It is quite evident from the results presented in this figure that the higher the solar radiation the higher the thermal conversion efficiency. It is also quite evident from the results presented in this figure that the higher the solar radiations the higher the thermal heat released and its efficiency.

Equations (18) through (24) were used to determine the heat released by the condenser section of the heat pipe. In order to analyze the results of this heat released by the condenser section of the heat pipe, Figure. 10 has been constructed to show the heat released by the condenser section of the heat pipe filled with water as working fluid and plotted at different solar radiations and heat pipe temperatures. It is quite clear from the results presented in this figure that the higher the solar radiation the higher the heat released by the condenser section of the heat pipe. Furthermore, at specific solar radiation higher heat pipe temperatures result in higher heat released at the condenser section.

The thermal heat transferred to the heat pipe evaporator section as well as the heat pipe temperatures are plotted and presented in Figure. 11 at different solar radiations for the heat pipe using water as working fluid. The data presented in Figure .11 was necessary to examine the impact of the solar radiation on the heat pipe's performance. It is quite clear from the results presented in this figure that the higher the solar radiations the higher the evaporator temperatures and obviously the higher the thermal heat transferred to the heat pipe evaporator section. Similar behavior has been observed for the other refrigerants used in this investigation. Comparison between the heats released at different refrigerants used as working fluids is also discussed elsewhere in the paper.

In addition, Figure.11 clearly quantifiesthe heat absorbed by the evaporator section of the heat pipe using water as working fluid at different solar radiations. Furthermore, it can be noticed also that at constant solar radiation, higher heat transfer fluid temperatures result in higher heat absorbed by the evaporator section.Consequently, this enhances the heat released by the condenser section of the heat pipe and the heat pipe energy conversion efficiency.

The Efficiency of Heat pipe filled with water as working fluid can be calculated from equations (28) through (29). Figure12. has been constructed to demonstrate the heat pipe efficiency at different solar radiations and heat pipe temperatures. It appears from the results presented in this figure that the higher the heat pipe temperature the higher the heat pipe efficiency. However, it was observed that higher solar radiations do not necessarily result in higher heat pipe efficiency. This could be attributed to the fact that higher solar radiation results in higher thermal heat transfer to the heat transfer fluid and consequently to the evaporator section of the heat pipe. However, the thermal capacity, the characteristic of the working fluid, the wick and the container of the heat pipe determine the condenser section thermal capacity of the heat pipe as per equations (17) through (24), and confirmed by Tardy and Sami [20], Endale [9] and Reay and Kew [23]. It is believed that the limitations imposed by the aforementioned determine the amount of heat released by the condenser section of the heat pipe. This could result in higher heat losses during the energy transfer process inside the heat pipe at higher solar radiation. Therefore, it is believed that the higher solar radiation does not necessarily result in higher heat pipe efficiency. It is important that the design of the heat pipe is based upon the site solar radiation and selection of the appropriate geometry of the heat pipe to maximize the energy conversion efficiency of the heat pipe at this particular solar radiation. 
Further to the aforementioned discussion and the results presented in Figure.12, Figure.13 has been constructed to present the efficiency of Hybrid system of PV-Thermal and heat pipe filled with water as working fluid at different solar radiations for one solar PV panel and two heat pipes and discuss the dependency of the hybrid system efficiency on the solar radiation. The hybrid system energy conversion efficiency for harnessing energy from solar energy using of photovoltaic-thermal solar panel and heat pipe is calculated using equation (29). As previously discussed, and from the analysis of the results presented in figure .12, it can be easily pointed out that the higher the heat pipe temperature the higher the hybrid system efficiency. However, it is also believed that the higher solar radiation does not necessarily result in higher hybrid system efficiency.

Figure14. Presents the impact of the different refrigerants under investigation on the thermal heat released under $750 \mathrm{w} / \mathrm{m}^{2}$ solar radiations, by the condenser section of the hybrid system composed of one single solar PV panel and two heat pipes core imbedded in the thermal tank. As previously discussed and stated the working fluid thermodynamic and thermo physical properties are very important parameters in determining the amount of the thermal heat absorbed from the solar collector, transferred and released by the heat pipe that is used to heat up the water in the thermal tank for further use.

It is quite clear from the data displayed in this figure that the heat released by the condenser section of the heat pipe is significantly impacted by the characteristics of the heat pipe and the type of working fluid filled in. The data in this illustrative figure also shows that the lower the boiling point among the refrigerants; R-32 and R-125 the higher the heat released by the condenser section of the heat pipe. This is attributed to the greater temperature difference potential between the working fluid saturation temperature inside the heat pipe and the surrounding water temperature in the thermal tank. In addition, it can also be noticed from this figure that the higher the temperature of the heat pipe the higher the thermal heat released by the condenser section of the heat pipe. This is one of the most important features of using a heat pipe to transfer thermal heat released by the PV panel into the thermal tank with the help of the natural circulation of the working fluid inside the heat pipe and the solar radiation.

On the other hand, Figure.15 displays the thermal heat released into the thermal tank from the condenser section of the two heat pipes using water and different refrigerants as working fluids under solar radiation of $750 \mathrm{w} / \mathrm{m}^{2}$.It can be shown that the lower the boiling point of among the refrigerants such as; R-32 and R-125 the higher the heat released by the condenser section of the heat pipe. This is similar to what has been observed and discussed of the results of the different working fluids displayed in Figure.14.

The dynamic behavior of the fluid flow of the heat transfer fluid (HTF) flowing in the thermal tubes beneath the PV solar cell is determined by equations (11) through (17) and plotted in Figure 16 under different solar radiations. The results indicated that the systems stabilized after 1200 second and the desired water flow outlet was reached after this time elapse as shown in Figure.7. As expected the heat transfer fluid mass flow rate increased at higher solar radiationand stabilized at 1200 seconds. This is due to the fact that the higher solar radiation results in higher thermal energy transferred to the fluid flow at constant temperature difference across the fluid flow and consequently, this increases the fluid flow mass flow rate. Furthermore, the results presented in this figure also suggest that the fluid flow mass flow rate is quasi constant during the thermal conversion process.

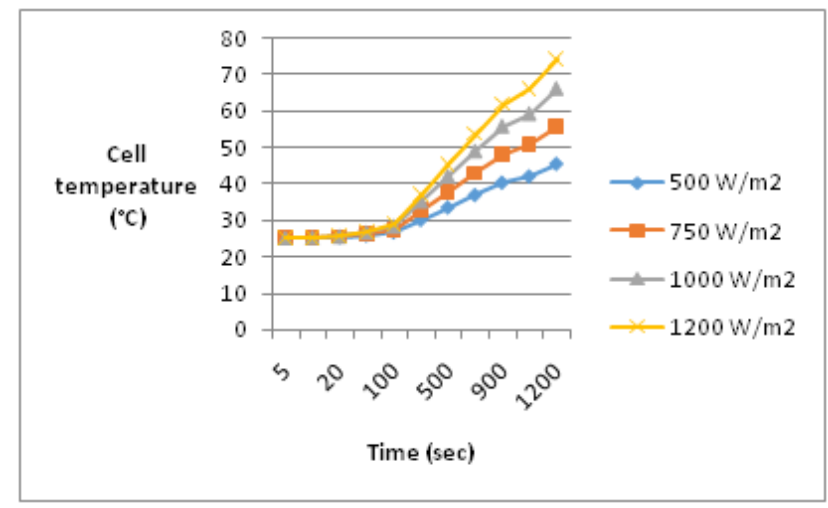

Figure5. $P V$ Cell temperature at different solar radiations and temperature difference $15^{\circ} \mathrm{C}$ 


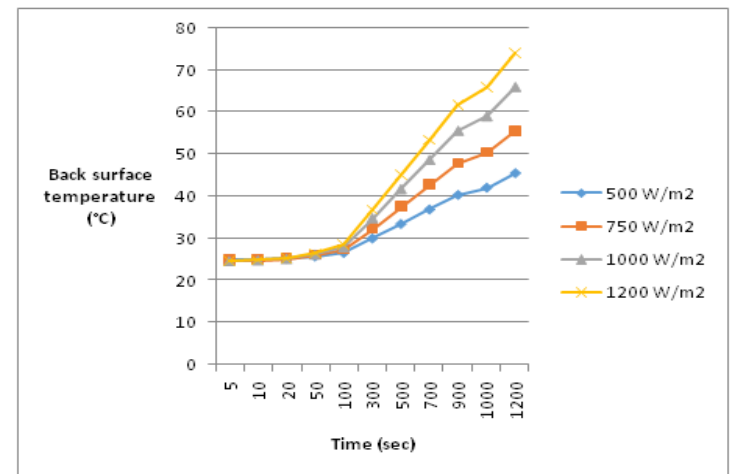

Figure6. Back PV Cell temperature at different solar radiations and heat exchanger temperature difference $15^{\circ} \mathrm{C}$.

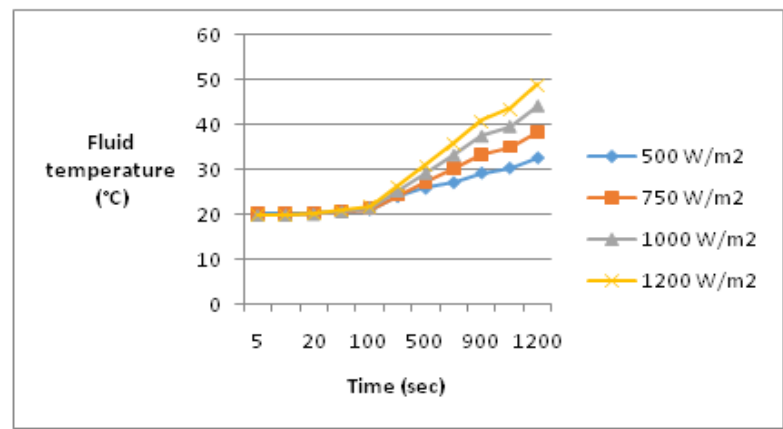

Figure7. Fluid temperature exiting the thermal pipes at heat exchanger temperature difference $15^{\circ} \mathrm{C}$

The series of numerical calculations using equation (26) have concluded that the Solar PV efficiency for one solar PV panel at different solar radiationsis quasi constant and is $22.38 \%$. This is based upon based upon the geometrical configuration of the solar PV panel reported in reference [22].

Furthermore, as shown in Figure.1, this novel concept is intended to enhance the energy conversion and efficiency of the PV-Thermal solar hybrid system through utilizing the excess thermal energy dissipated from the conversion process of the PV panel. Thisin turn drivesthe heat pipesto produce domestic hot water, DHW, and obviously,the end result is to enhance energy conversion and efficiency of the solar photovoltaic hybrid system.However, the PV solar panel efficiency remains constant at $22.38 \%$ and is independent of the type of working fluid filled in the heat pipes.

Figure.17 presents the dynamic water temperature history in the thermal tank resulting from the heat released by the condenser section of the two heat pipes using different refrigerants as working fluids.Equation (18) is used to describe the mass and energy balances under natural convection heat transfer in the thermal tank for a single-control volume of heat pipe submerged in the thermal tank [9] and is used to calculate the water temperature plotted in this figure. The results presented in this figure clearly demonstrate that no significant impact of the working fluid type filled in the heat pipe on the water temperature variations. This can be attributed to the fact that the difference between the second and third terms of equation (18) is quasi-independent of the type of refrigerant filled in the heat pipe. However, as shown in Figure.15, the amount of thermal heat transferred into the thermal tank depends upon the type of refrigerant filled in the heat pipe.

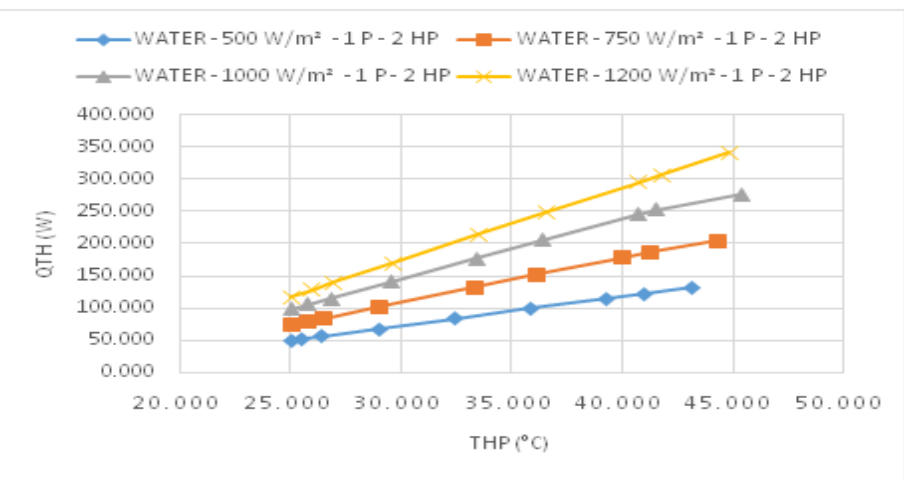

Figure8. Heat released at different solar radiations at one solar PV panel at different heat pipe temperature and two heat pipes filled with water. 
Prediction of Performance of a Novel Concept of Solar Photovoltaic-Thermal Panel and Heat Pipe Hybrid System

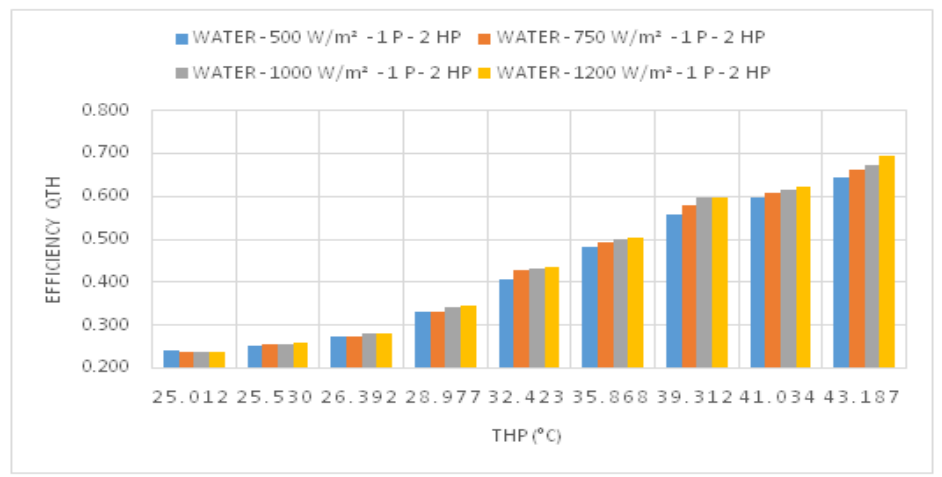

Figure9. Efficiency of Heat released at different solar radiations and temperatures at one solar PV panelwith two heat pipes filled with water.

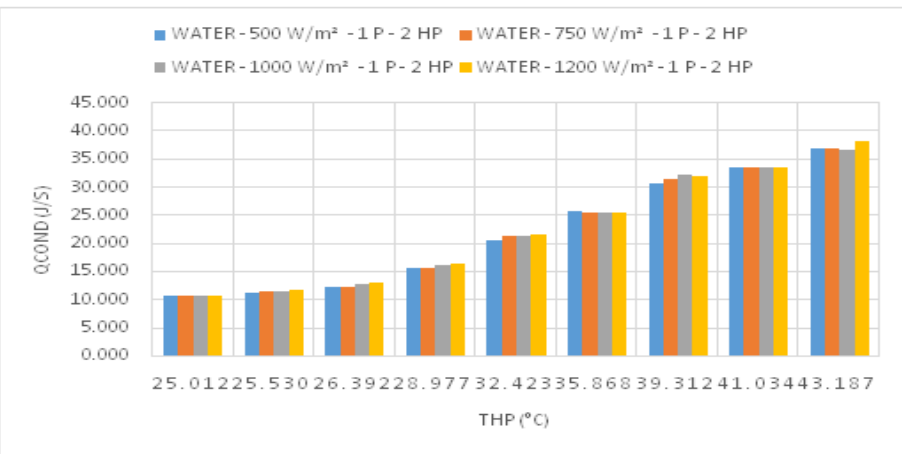

Figure10. Heat released by the condenser section of the heat pipe using water as working fluid and at different solar radiations.

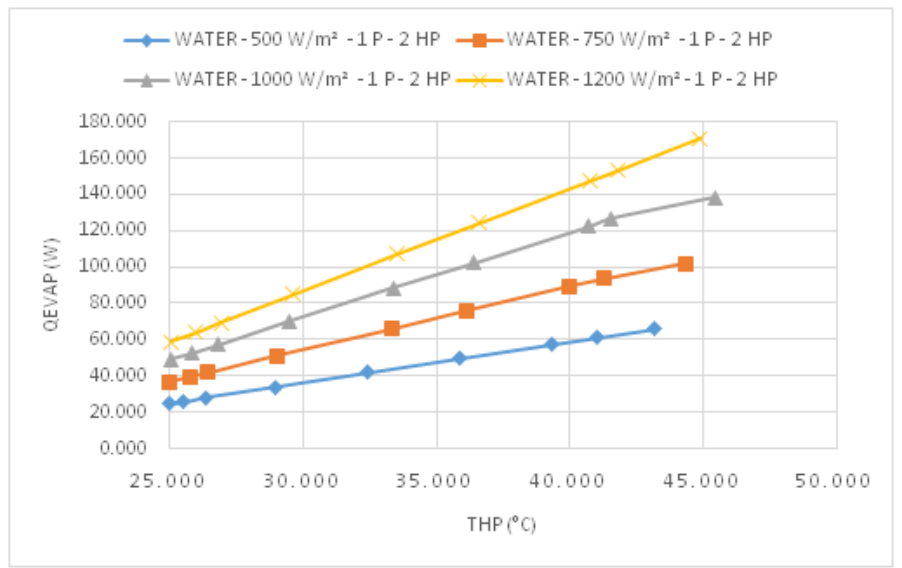

Figure11. Heat absorbed by the evaporator section of the heat pipe using water as working fluid and at different solar radiations.

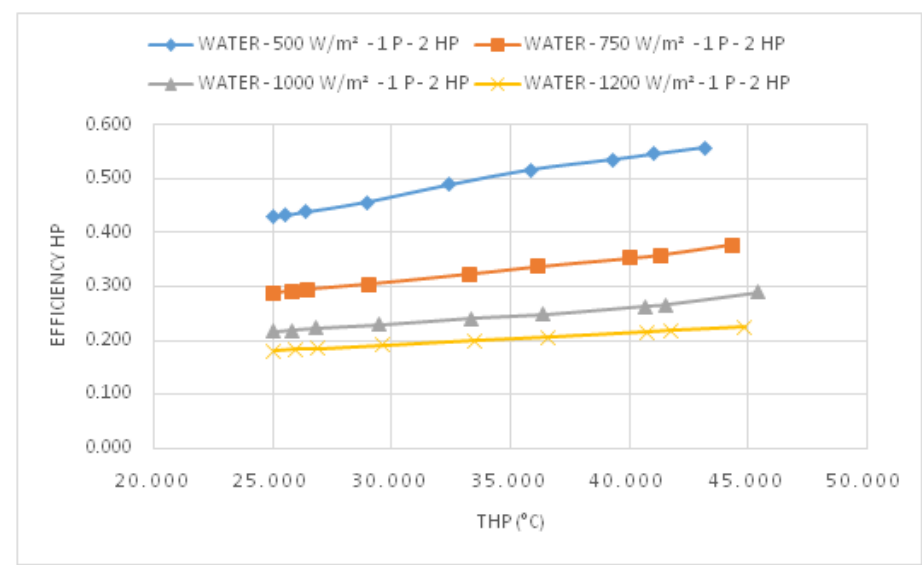

Figure12. Efficiency of Heat pipe filled with water at different solar radiations at one solar PV panel and two heat pipes. 
Prediction of Performance of a Novel Concept of Solar Photovoltaic-Thermal Panel and Heat Pipe Hybrid System

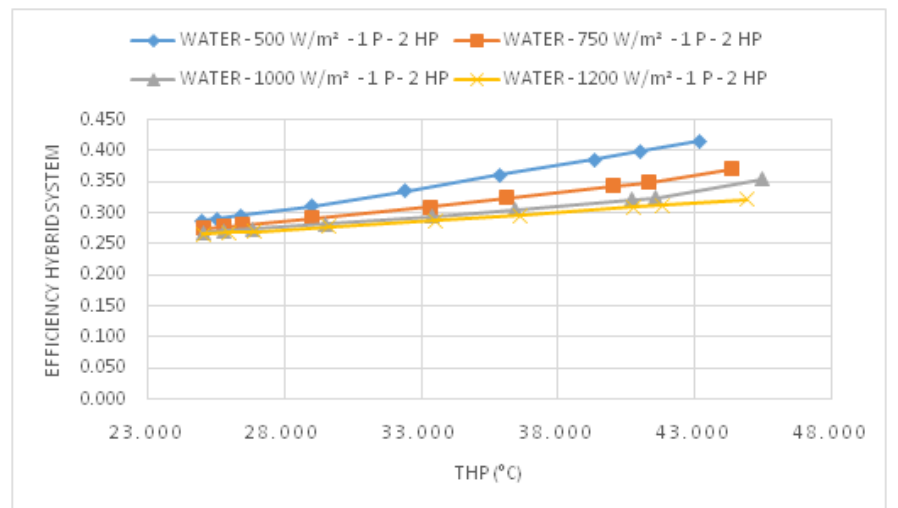

Figure13. Efficiency of Hybrid system with heat pipe filled with water at different solar radiations at one solar $P V$ panel and two heat pipes.

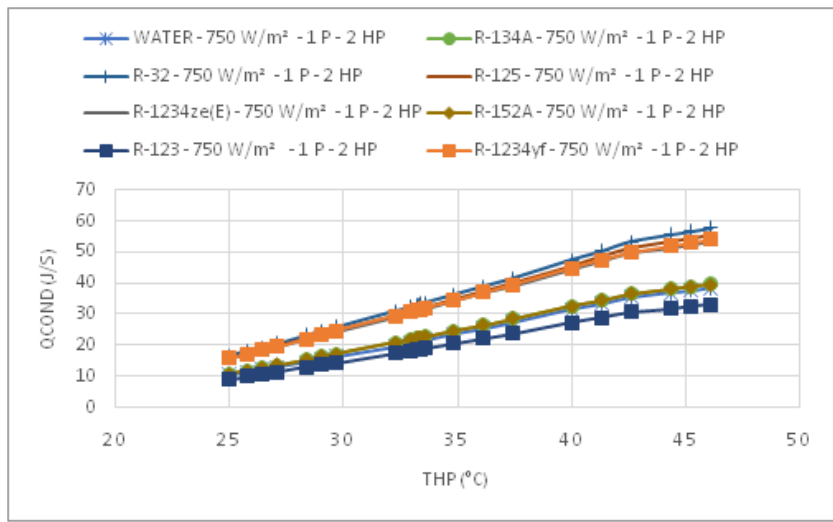

Figure14. Heat released by the condenser section of a single heat pipe using different refrigerants as working fluid.

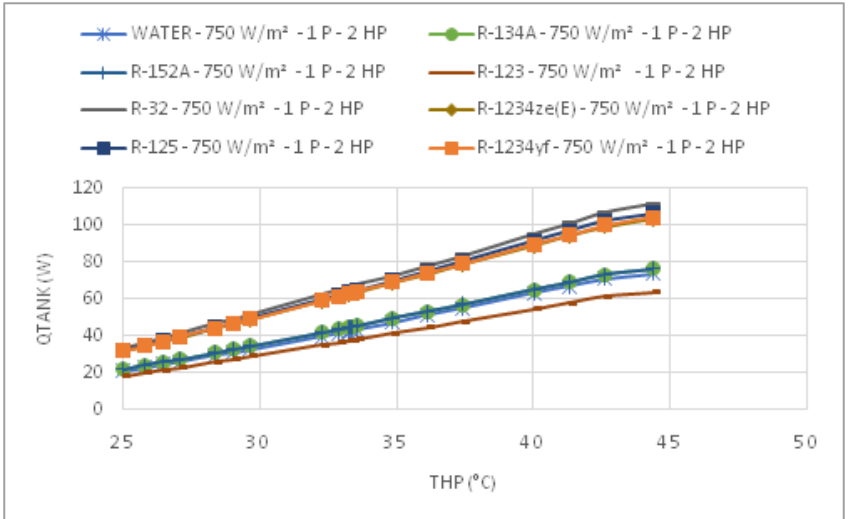

Figure15. Heat released by the thermal tank using different refrigerants as working fluids

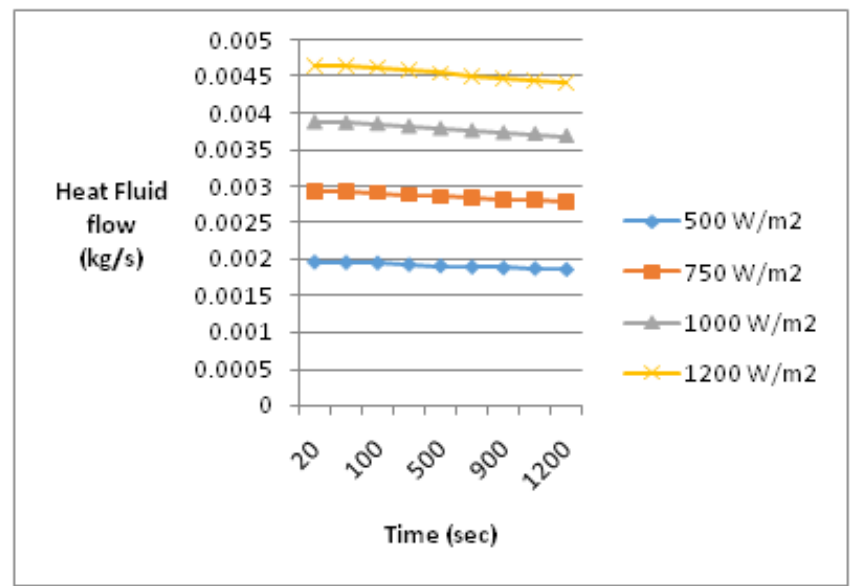

Figure16. Heat transfer fluid flow rate at different solar radiations for one solar PV panel equipped with two heat pipes 


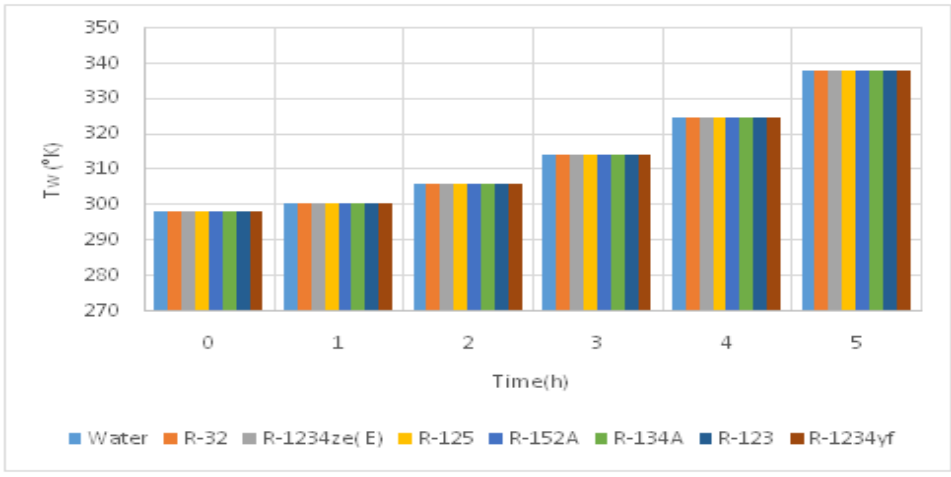

Figure17. Water temperature in the thermal tank with condenser section of the two heat pipes using different refrigerants as working fluid.

Furthermore, examining the results presented infigure 11 through 17 clearly indicates that the higher the solar radiations the higher the evaporator temperatures and obviously the higher the heat released from the heat pipe condenser.

Figure 18. has been constructed to show the profile of water temperature in the thermal tank under different solar radiations; 500 through $1200 \mathrm{w} / \mathrm{m}^{2}$ and at different heat pipe temperatures with water as a working fluid filled in the heat pipe. The results displayed in this figure are for one PV solar panel and two heat pipes. It is evident from the results displayed in this figure that the higher the solar radiation the higher the water temperature in the thermal tank. This is attributed to the fact that the higher the solar radiation the higher the thermal energy transferred to the evaporator section of the heat pipe and consequently to the condenser section of the heat pipe and the thermal tank. It is quite important to the designer of this system to properly select the site where the solar radiation is the highest to benefit from the higher thermal energy transferred to the water in thermal tank and obviously will result in higher thermal efficiency of the system in question.

Similar behavior has been observed with the other refrigerants used in the heat pipe under investigation. Comparison between the thermal heats released at different refrigerants is discussed elsewhere in the paper and Figure 19.

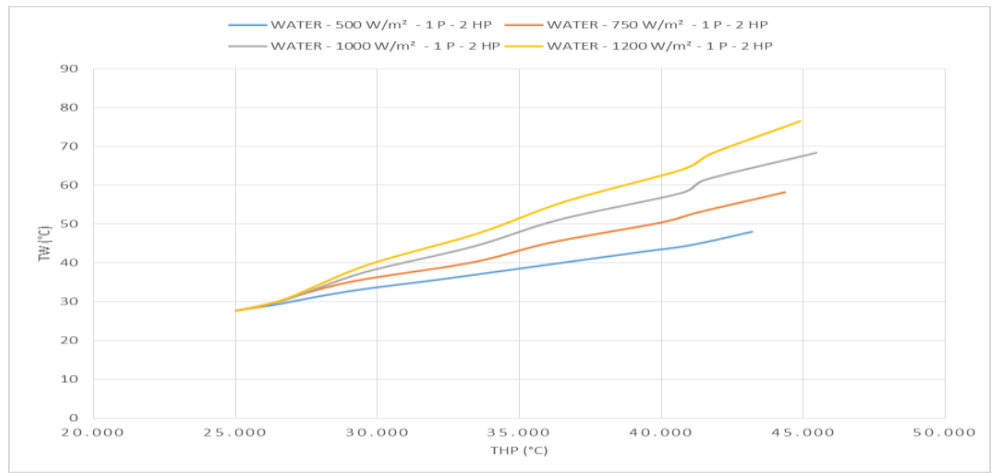

Figure18. Water temperature in the thermal tank as a function of the heat pipe temperature

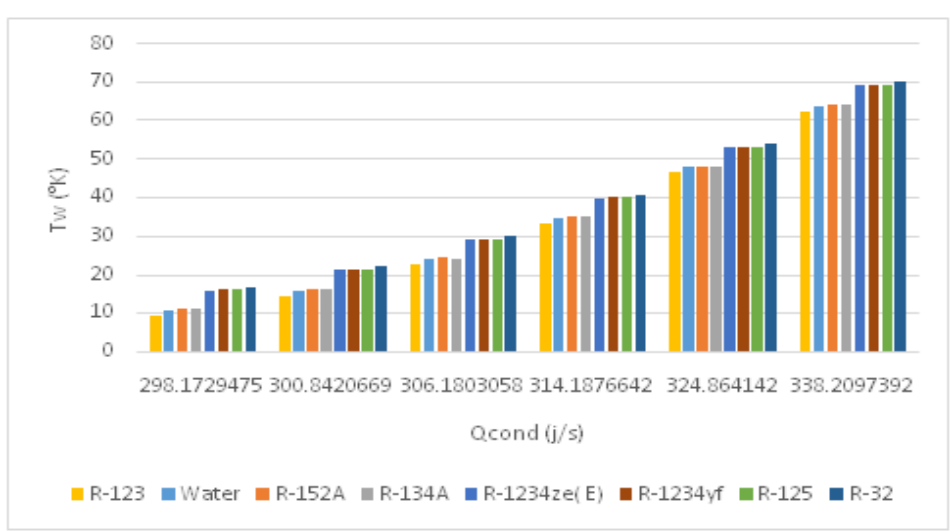

Figure19. Water temperature in the thermal tank at different condenser thermal heat and $750 \mathrm{w} / \mathrm{m}^{2}$ 
On the other hand, Figure.19 displays the water temperature in the thermal tank at different thermal heats released by the condenser section with two heat pipes using different refrigerants as working fluid at solar radiation of $750 \mathrm{w} / \mathrm{m}^{2}$. It is evident from the data displayed in this figure that the higher the thermal heat released by the condenser section of the heat pipe the higher the water temperature in the thermal tank. In addition, the data displayed in this figure also demonstrate that refrigerants R-32 and R-125 used as working fluids in the heat pipe have the highest thermal energy released by condenser andresults in the highest water temperature in the thermal tank. This is attributed to the significant difference between the boiling point temperatures of those refrigerants and the water temperature in the thermal tank. It was also observed that R-1234zef and R-1234yf induce higher water temperatures. It is also worthwhile noting that similar behavior has been observed with other solar radiations namely; 500, 1000 and $1200 \mathrm{~W} / \mathrm{m}^{2}$

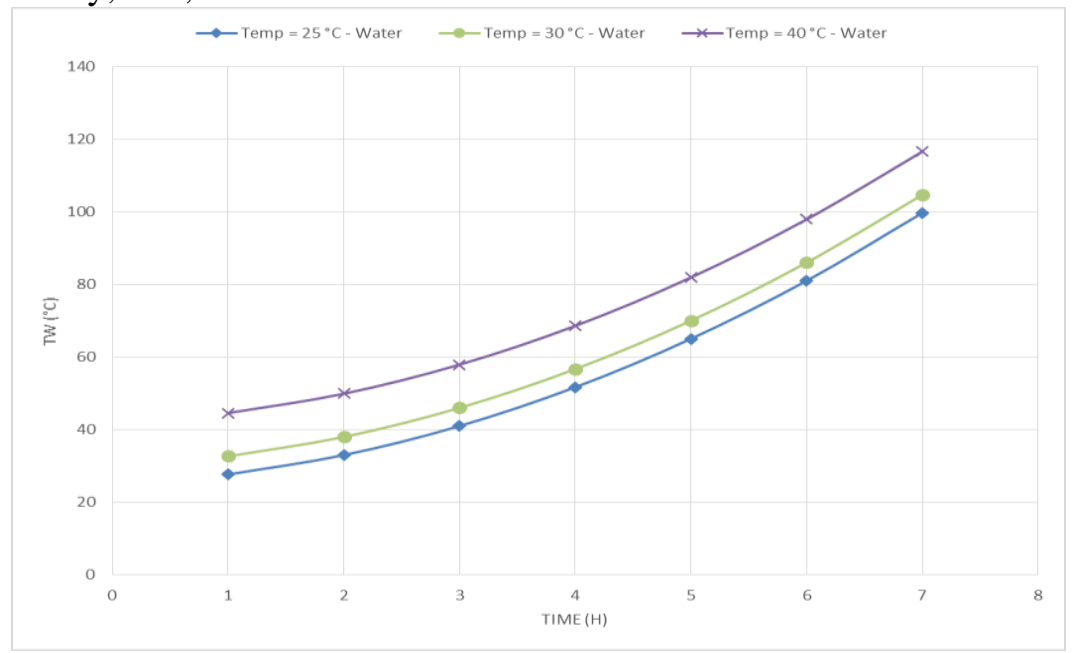

Figure20. Water temperature dynamic profile in the thermal tank.

The dynamic behavior of the water temperature in the thermal tank is plotted in Figure. 20 against time for different supply water temperatures from the thermal tubes welded under the PV solar panel. It is quite clear from the data presented in this figure that the higher the supply temperature from the solar collector the higher the water temperature in the thermal tank. In addition, it can be pointed out that it takes 5-7 hours for the water temperature in the thermal tank to reach the level required for domestic or industrial use as shown in the figure,depending upon the thermal tubes supply temperature.Also, as previously discussed the higher the solar radiation the higher the supply water temperature from thermal tubes, therefore, the higher the solar radiation the higher the water temperature in the thermal tank.

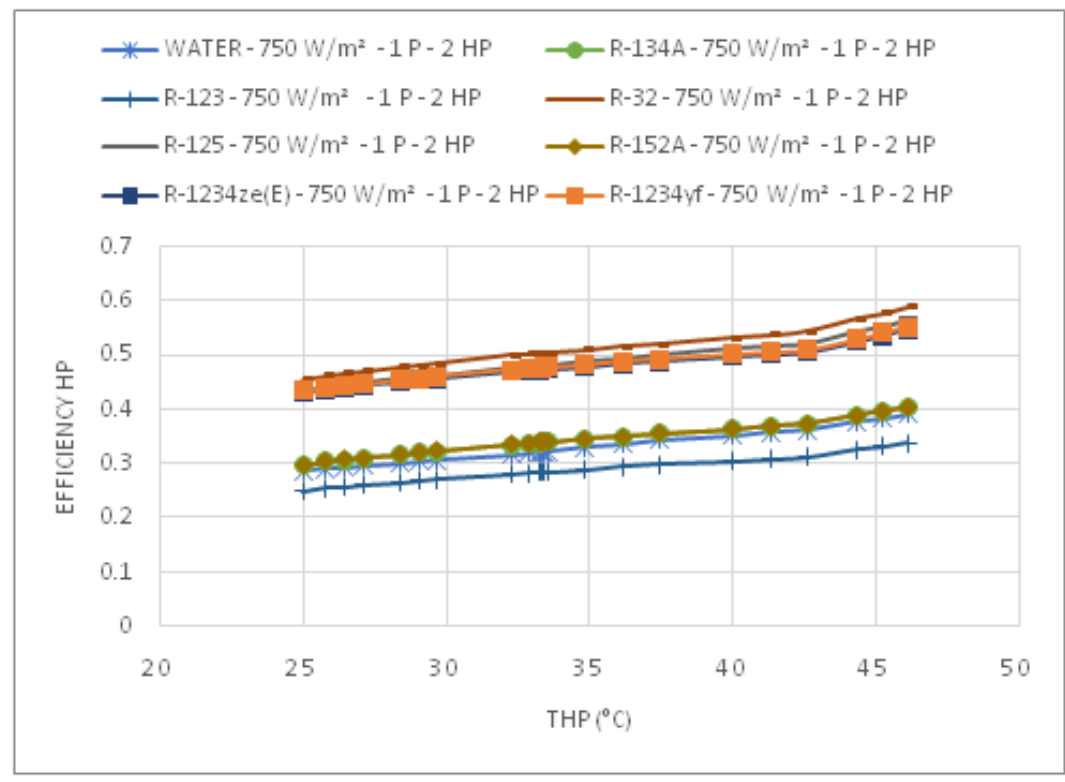

Figure21. Heat pipe efficiency at different working fluids and at $750 \mathrm{w} / \mathrm{m}^{2}$ 
Prediction of Performance of a Novel Concept of Solar Photovoltaic-Thermal Panel and Heat Pipe Hybrid System

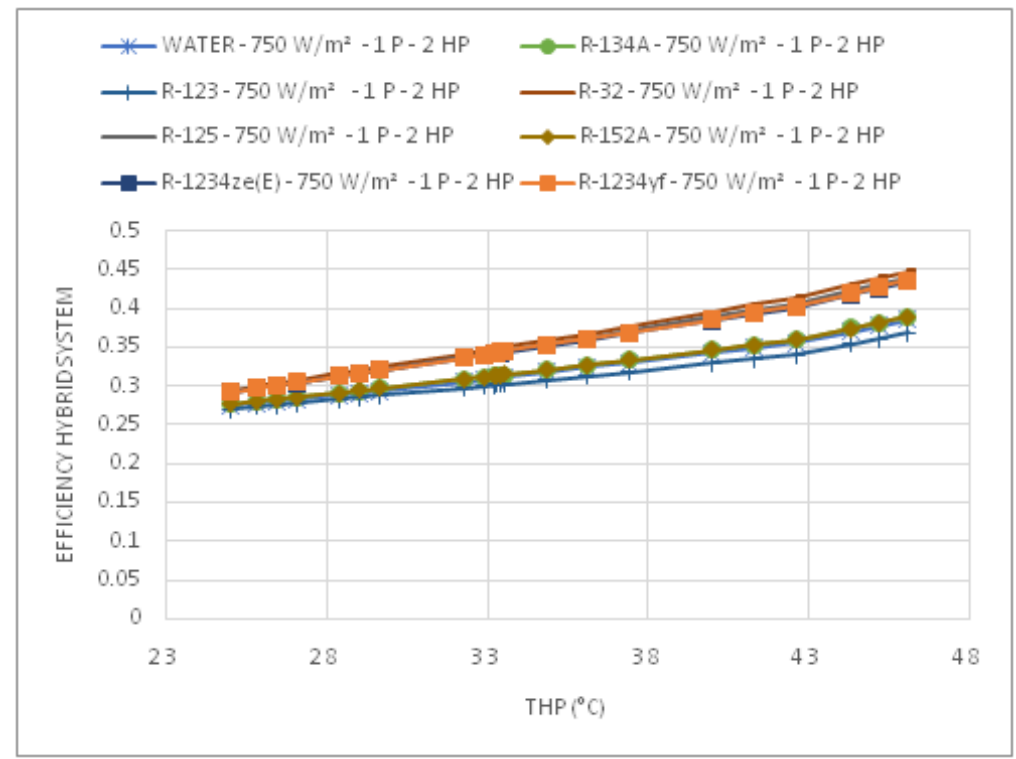

Figure22. Hybrid system efficiency at different working fluids and at $750 \mathrm{w} / \mathrm{m}^{2}$

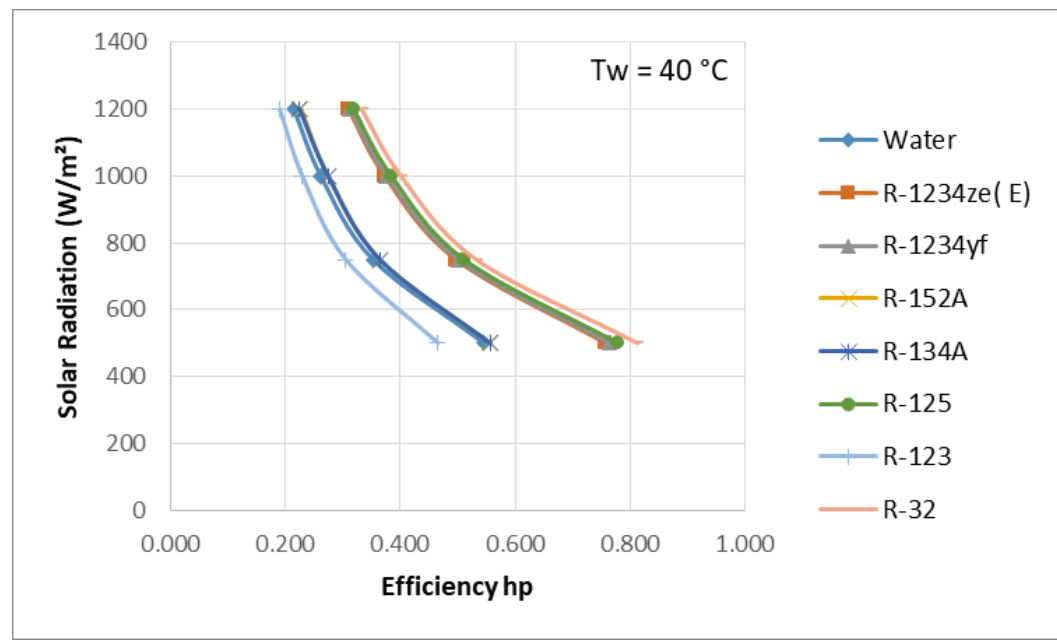

Figure23. Hear pipe efficiency at different working fluids.

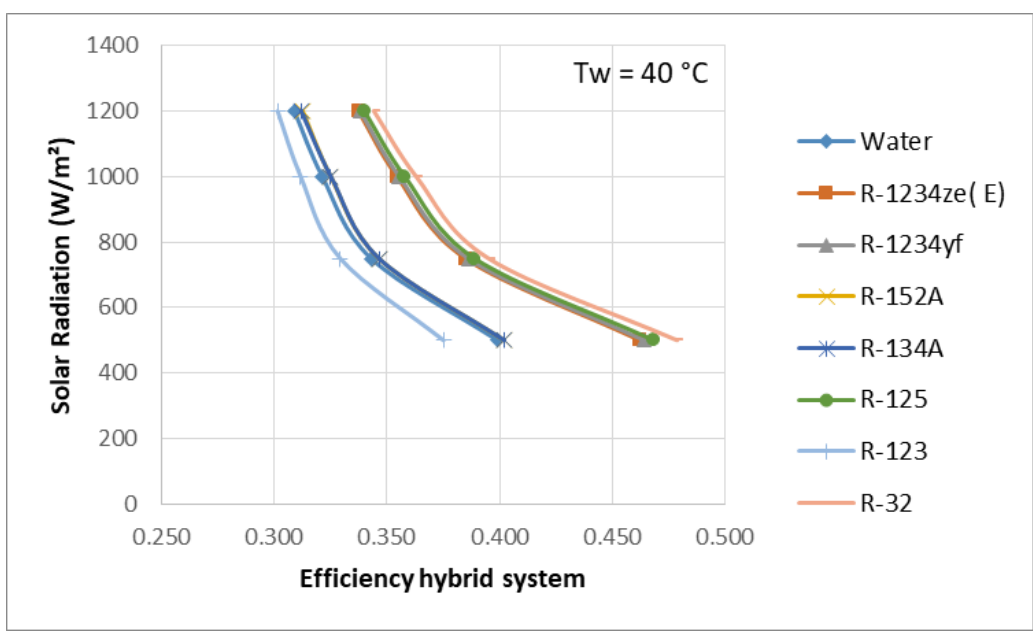

Figure24. Hybrid system efficiency at different working fluids.

Another two important characteristics of the solar PV-thermal system integrated heat pipesare presented in Figures 21 and 22; where the heat pipe and hybrid system efficiencies are shownat different solar radiations.It should be noted that the hybrid system efficiency is defined as per equation (29) by the amount of electrical power and thermal energy released at the thermal tank side for further use, divided by the solar radiation. The data presented in these figures show that the higher 
the solar radiation the lower the efficiency of the heat pipe and hybrid system. However, the results displayed in these figures also show that thehigher efficiencies of the heat pipe and hybrid system were observed with R-32 and R-125 used as working fluids in the heat pipe. The data displayed in this figure clearly show that among the refrigerants under investigation, R-125 and R-32, R1234ze and R1234yf have the higher thermal energy delivered to the thermal tank. This is significant, and therefore, it is recommended that the aforementioned refrigerants be used in the heat pipe as working fluids for this particular application.

As previously discussed at higher solar radiationsand demonstrated in Figures 23 and 24, more heat losses are encountered.This is due to the low boiling point of refrigerants, heat is transferred at a faster rate. This consequently impacts the system efficiencies.Therefore, we feel that the observed behavior in the aforementioned figuresis attributed to the heat losses during the heat transfer process to the thermal tank as reported by reference [32].

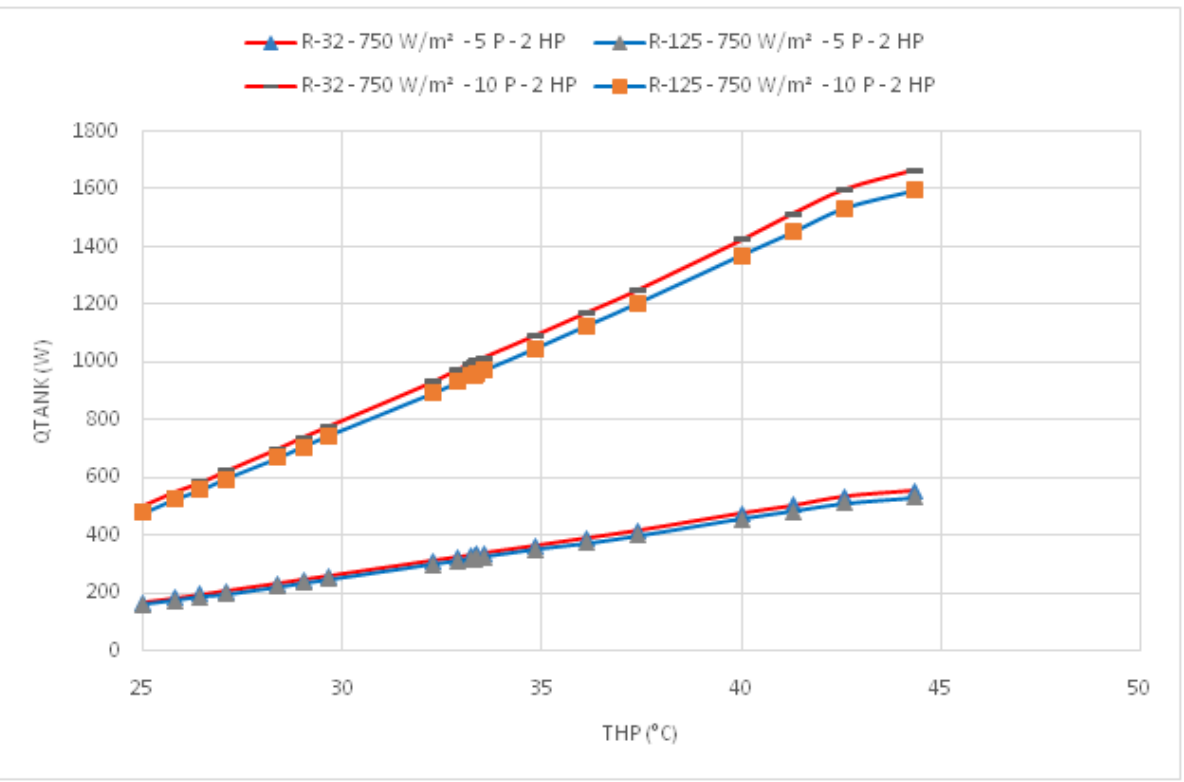

Figure25. Thermal energy released in the thermal tank at different number of solar panels.

Furthermore, in order study the impact of the number of solar PV panels on the thermal heat released into the thermal tank, Figure .25 has been constructed where the thermal heat released into the thermal tank generated by 5 and 10 solar PV panels was displayed at 750 solar radiation $\mathrm{W} / \mathrm{m}^{2}$ and using the most promising refrigerants R-125 and R-32 filled in the heatpipe that yielded the maximum efficiency of the hybrid system among the other refrigerants under investigation.It is evident from the data presented in this figure that the higher number of solar PV panels the higher the thermal heat released into the water in the thermal tank from the condenser section of the heat pipes. Also,it should be noted that the data presented in this figure showed similar trends to those displayed previously of the thermal heat released by the condenser section of the heat pipe.

Furthermore, as the aforementioned discussion regarding the novel hybrid system in question illustrates that it is imperative for the designer of the PV-T integrated heat pipe to ensure that the PV solar panel characteristics and cell temperatures, site solar radiation of the site, the ambient conditions and the refrigerant characteristics and thermodynamic properties are taken into consideration in the decision-making process.

\section{MOdel VALidation}

In order to validate the numerical model prediction describing the behavior of the novel hybrid system under investigation in Equations (1) through (29), only data available in the literature for the solar PV panel and related systems was used for comparison. In the following sections, we discuss the model validation and present the different comparisons. Furthermore, as has been discussed, the basic simulation model is established after the mass and energy balances of the PV solar panel, its characteristics such as; cell temperatures and dissipated thermal energy from the solar PV panel and absorbed by the heat transfer fluid. Therefore, it was felt that validation of the PV solar panel model 
should demonstrate strong confidence in the results predicted hereby. To this end, Figures 26 through 28have been constructed to compare the proposed model prediction of the PV solar panel, its characteristics and the PV Thermal parameters with the data reported in the literature on the solar PV namely, references $[9,17$, and 30$]$.

In particular, as shown in Figure 26, it is quite apparent from the comparison presented in the figure that the model prediction fairly compares with the data of the dynamic PV cell temperature presented by Faragali et al. data [17]. The comparison presented in this figure also showed that the model and data have the same trend as the data, however, some discrepancies exit. It is believed that the discrepancies are due to the fact that the Faragali et al. [17] did not provide full disclosure of the various parameters used in equations (6) through (9) and Reference Rajapakse et al. [30] had to be consulted on the various missing parameters in Faragali et al. [17]. However, as pointed out in references [8, 12, and 17] taking into account the complexity of the PV cell temperature phenomena and its thermal behavior, we feel that our model fairly predicted the PV cell dynamic profile.

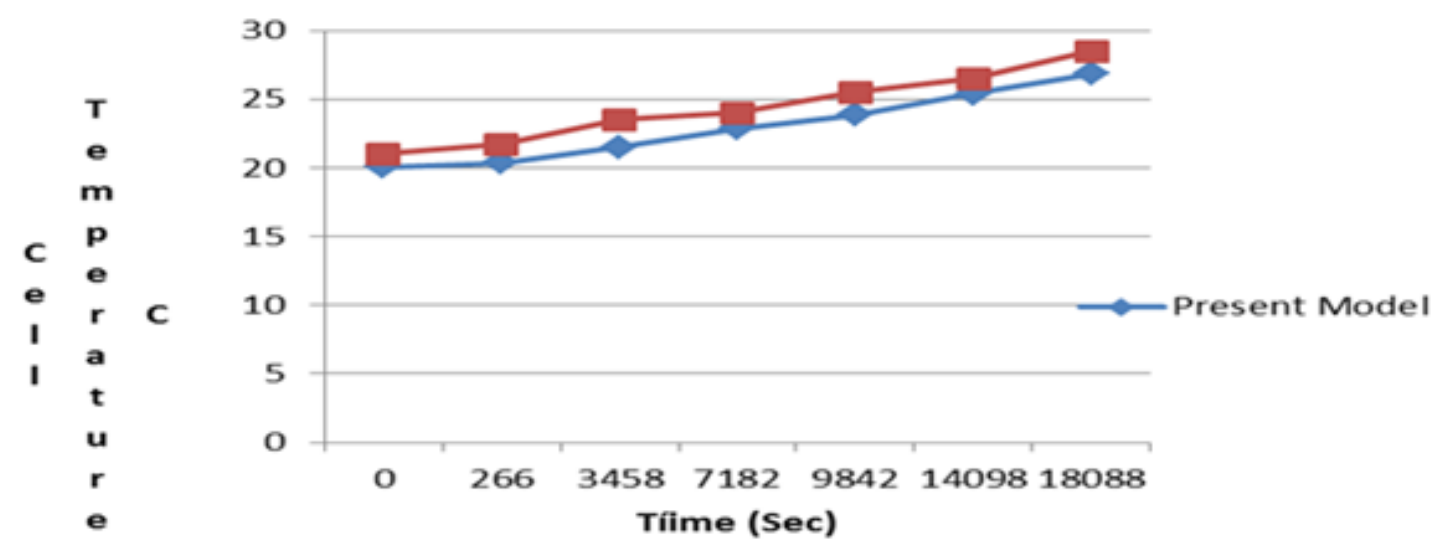

Figure26. Model's validations for cell temperature [17].

Furthermore, Figure. 27shows a comparison between model's prediction and experimental data presented in [17,30], where the numerical prediction of the aforementioned solar PV model of the typical characteristics of a solar PV panel; power and different amperages are displayed. It is worthwhile mentioning that PV panel amperage varies with solar radiations. It can be seen from this figure that the present model predicted very well the solar PV characteristics. Since the present model is an extension of the solar PV model and work of Sami and Campoverde [27], we strongly feel that current model is reliable.

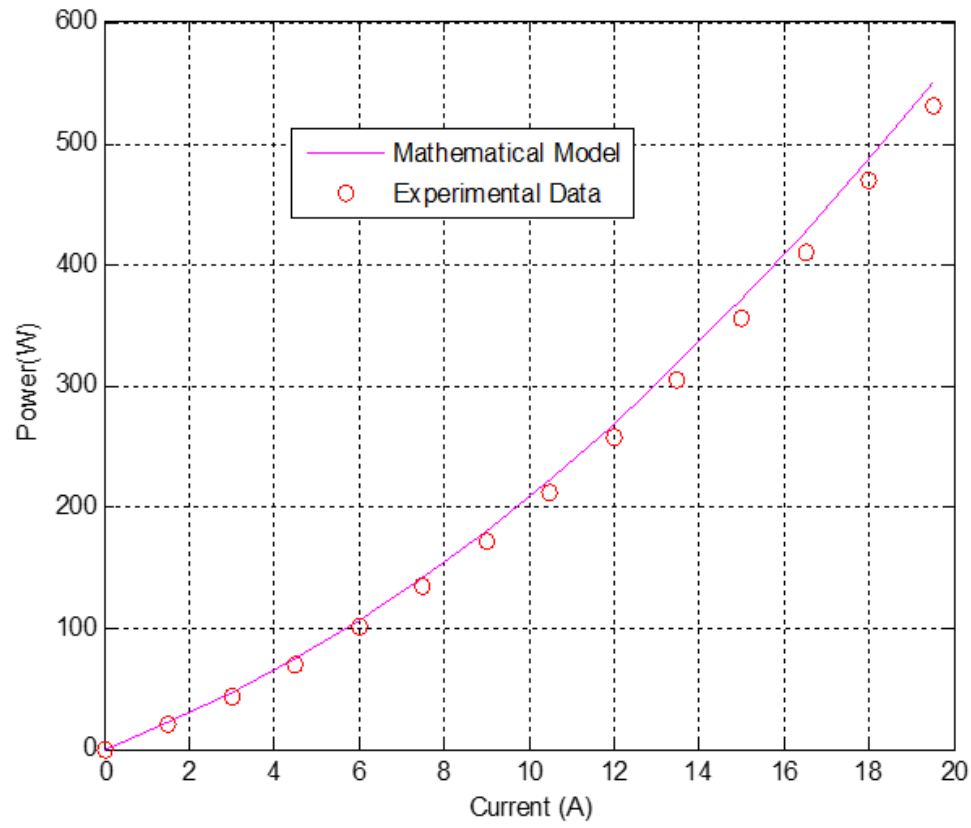

Figure27. Comparison between model and experimental data [17, 27, 30] 


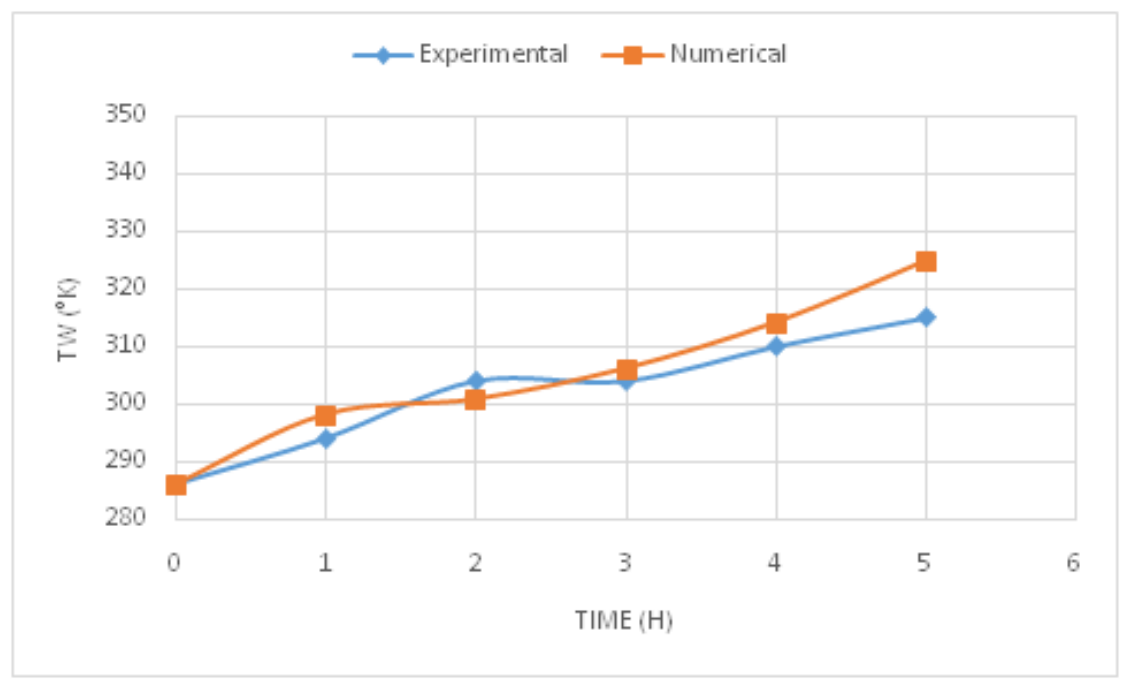

Figure28. Comparison between model and experimental data [9]

Finally, the comparison displayed in Figure. 28 between model's prediction of the water temperature in the thermal tank and the experimental data reported in reference [9], demonstrated clearly that our model predicted fairly the dynamic data of the water temperature in the tank where the condenser section of the heat pipes was placed. It also can be noticed that some discrepancies exit between the model's prediction and the data which are attributed to the heat losses and the calculation of the heat transfer coefficient in the thermal tank.

\section{CONCLusion}

The energy conversion equations describing the mass and energy balances have been developed, integrated, and solved to predict the dynamic performance, efficiencies and the key important parameters of the hybrid system Solar PV Thermal and heat pipe under investigation. The model is based on dynamic mass and energy equations coupled with the heat transfer coefficients, and thermodynamic constants, refrigerants properties and as well as material properties. This hybrid system is composed of the novel combined concept of a photovoltaic-thermal solar panel PV and heat pipe. This current study is presented under different parameters such as solar irradiance, material properties, and boundary conditions for the solar PV panel as well the heat pipe filled with different refrigerants such as water, R-134a, R-152a, R-32, R-125, R1234fz, and R-1234fy and R-123

As PV solar panel efficiency calculations showed the higher the solar radiation the higher solar PV current and consequently this increases the solar PV power output, however, the PV solar panel efficiency remains constant at $22.38 \%$.

It is quite clear from the results presented during the course of this investigationthat the higher the solar radiations the higher the evaporator temperatures of the heat pipe and obviously the higher the thermal heat transferred to the heat pipe evaporatorsection and consequently the higher the heat released from the heat pipe condenser section in the thermal tank. Furthermore, the data also shows that the higher solar radiation the higher the water temperature into the thermal tank which is intended to supply to the domestic or industrial demands.

In addition, the data presented also demonstrated that the refrigerant R-32,R-125, R1234fz, and R1234 fy yield the maximum efficiency of the hybrid system among the other refrigerants under investigation.

Finally, it is evident that the present model predicted well the solar PV characteristics and the thermal behavior of the heat pipes as well as the thermal tank water temperature dynamic profile.

NOMENCLATURE

Area cell PV cell area $\left(\mathrm{m}^{2}\right)$

Area pipe Pipe area $\left(\mathrm{m}^{2}\right)$

Area ${ }_{\mathrm{HT}}$ Heat transfer area $\left(\mathrm{m}^{2}\right)$ 
$\mathrm{C}_{\mathrm{p}_{-} \text {water }}$ Thermal capacity of water $(\mathrm{J} / \mathrm{kgK})$

D Internal Pipe diameter (m)

$\mathrm{E}_{\mathrm{gO}}$ Bandgap energy of semiconductor $(1.1 \mathrm{eV})$

$\mathrm{G}$ Total Solar radiation incident on the PV module $\left(\mathrm{W} / \mathrm{m}^{2}\right)$

$\mathrm{H}$ Convective heat transfer coefficient module $\left(\mathrm{W} / \mathrm{m}^{2} \mathrm{~K}\right)$

$\mathrm{h}_{\text {water }}$ Heat transfer coefficient $\left(\mathrm{W} / \mathrm{m}^{2} \mathrm{~K}\right)$

I Output current of the PV module (A)

$\mathrm{I}_{0}$ Diode saturation current per module (A)

$\mathrm{I}_{\mathrm{ph}}$ Light generated current per module or photocurrent (A)

$\mathrm{I}_{\mathrm{rs}}$ Module reverse saturation current (A)

$\mathrm{I}_{\mathrm{sc}}$ Short circuit current (A)

K Boltzmann's constant $\left(1.3806503 * 10^{-23} \mathrm{~J} / \mathrm{K}\right)$

Ki Short-circuit of a Pv cell at $\mathrm{SRC}\left(\mathrm{mA} /{ }^{\circ} \mathrm{C}\right)$

$\mathrm{K}_{\mathrm{Pv}}$ Thermal conductivity of $\mathrm{Pv}$ cell $(\mathrm{W} / \mathrm{mK})$

$\mathrm{L}_{\text {cell }}$ Length of a Pv cell (m)

$\dot{\mathrm{m}}$ Water flow $(\mathrm{Kg} / \mathrm{s})$

$\mathrm{mC}_{\mathrm{p} \_ \text {module }}$ Thermal capacity of the Pv module $(9250 \mathrm{~J} / \mathrm{K})$

$\mathrm{m}_{\text {water }}$ mass of water $(\mathrm{Kg})$

$\mathrm{n}$ Ideality factor of the diode (q)

$\mathrm{N}_{\mathrm{p}}$ Total number of cells connected in parallel

$\mathrm{N}_{\text {pipes }}$ Number of pipes

$\mathrm{N}_{\mathrm{s}}$ Total number of cells connected in series

nTE number of Thermal Elements in a pipe

P Power generated by PV module (W)

q Electronic charge $(\mathrm{C})$

$\mathrm{Q}_{\text {conduction }}$ Energy due to conduction (W in Electrical Process) (W/m ${ }^{2}$ in Thermal Process)

$\mathrm{Q}_{\text {convection }}$ Energy due to convection (W in Electrical Process) (W/ $\mathrm{m}^{2}$ in Thermal Process)

$\mathrm{Q}_{\text {elect }}$ Electrical power generated (W)

$\mathrm{Q}_{\text {in }}$ Energy received due to Solar irradiation $\left(\mathrm{W} / \mathrm{m}^{2}\right)$

$\mathrm{Q}_{\text {in_cell }}$ Energy incident on one PV cell due to solar radiation $\left(\mathrm{W} / \mathrm{m}^{2}\right)$

$\mathrm{Q}_{\text {radiation }}$ Energy due to radiation (W/ $\mathrm{m}^{2}$ in Thermal Process)

$\mathrm{Q}_{\text {Thermal }}$ Energy from thermal process (W)

$R_{d}$ Fouling factor - or unit thermal resistance of the deposit $\left(\mathrm{m}^{2} \mathrm{~K} / \mathrm{W}\right)$

$\mathrm{R}_{\mathrm{s}}$ Diode series resistance per module $(\Omega)$

$\mathrm{R}_{\mathrm{sh}}$ Diode shunt resistance per module $(\Omega)$

$\mathrm{S}_{\mathrm{c}}$ Total surface area of PV cells in a module $\left(\mathrm{m}^{2}\right)$

$\mathrm{S}_{\mathrm{p}}$ Total area of the PV module $\left(\mathrm{m}^{2}\right)$

T Operating temperature $(\mathrm{k})$ 
T Time (s)

$\mathrm{T}_{\mathrm{a}}$ Ambient temperature $\left({ }^{\circ} \mathrm{C}\right)$

$\mathrm{T}_{\mathrm{C}}$ Pv Cell Temperature $\left({ }^{\circ} \mathrm{C}\right)$

$\mathrm{T}_{\mathrm{db}}$ Dry bulb temperature $\left({ }^{\circ} \mathrm{C}\right)$

$\mathrm{T}_{\mathrm{f}}$ Fluid temperature $\left({ }^{\circ} \mathrm{C}\right)$

$\mathrm{T}_{\text {fin }}$ Fluid temperature at inlet $\left({ }^{\circ} \mathrm{C}\right)$

$\mathrm{T}_{\mathrm{fHx}}$ Maximum temperature at the heat exchanger $\left({ }^{\circ} \mathrm{C}\right)$

$\mathrm{T}_{\mathrm{fH} x+1}$ Fluid temperature at thermal element $1(\mathrm{dx})\left({ }^{\circ} \mathrm{C}\right)$

$\mathrm{T}_{\mathrm{m}}$ Module Back-surface temperature $\left({ }^{\circ} \mathrm{C}\right)$

$\mathrm{T}_{\mathrm{r}}$ Nominal temperature $(298.15 \mathrm{~K})$

$\mathrm{U}$ Thermal conductance of clean heat exchanger $\left(\mathrm{W} / \mathrm{m}^{2} \mathrm{~K}\right)$

Ud Thermal conductance of heat exchanger after fouling (W/m2K)

V Output voltage (V)

$\mathrm{V}_{\mathrm{oc}}$ Open circuit voltage $(\mathrm{V})$

Vt Diode thermal voltage (V)

$\alpha_{\text {abs }}$ Overall absorption coefficient

$\eta_{\text {Hybrid }}$ Hybrid system efficiency

$\eta_{\mathrm{PV}}$ module efficiency

$\eta_{\text {Thermal }}$ Efficiency of thermal process

$\rho w$ Density of water vapor $\left(\mathrm{Kg} / \mathrm{m}^{3}\right)$

$\partial Q$ Convection heat transfer rate

Q Thermal heat $(\mathrm{kj} / \mathrm{s})$

$\varepsilon$ Emissivity PV cel

\section{ACKNOWLEDGEMENT}

The research work presented in this paper was made possible through the support of the Catholic University of Cuenca. The author also would like to thank Edwin Marin for his great help in performing the different computations.

\section{REFERENCES}

[1] D.J. Yang, Z.F. Yuan, P.H. Lee, and H.M. Yin, (2012), Simulation and experimental validation of heat transfer in a novel hybrid solar panel, International Journal of Heat and Mass Transfer 55 (2012) 10761082.

[2] Gang, P., Huide, F., Toa, Z., and Jie, J. (2011), A Numerical and Experimental Study on a Heat Pipe PV/T System, Solar Energy, 85, 911-921, 2011.

[3] Dai, N, Li, S., Zhang, Z, (2017), Simulation of Hybrid Photovoltaic Solar Assisted Loop Heat Pipe/Heat Pump System, Appl. Sci, 7, 2-15, 2017.

[4] Tripanagnostopoulos et al, (2002) "Hybrid photovoltaic/thermal solar systems. Sol Energy", 72, PP 21734.

[5] Bergene, O M Lovvik, (1995), "Model calculations on a flat-plate solar Heat-collector with integrated solar cells", Solar Energy, 55, PP 453-62.

[6] H.G. Teo, P.S. Lee, and M.N.A. Hawlader, (2012), An active cooling system for photovoltaic modules, Applied Energy 90 (2012) 309-315.

[7] Hashim, H, Bomphrey, J.J., Min, G., (2016),"Model for Geometry Optimization of Thermoelectric Devices in a Hybrid PV/TE System", Renewable Energy, 87, 458-463, 2016.

[8] H.P.Garge, R.K.Agarwal, (1995), "Some aspects of a PV/T collector/force Circulation flat-plate solar water heater with solar cells", Energ Convers Manage, 36, PP 87-99.

[9] Endalew,A., K., (2011)," Numerical modeling and experimental validation of heat pipes solar collector for water heating", KTH Industrial Engineering and Management, Sweden, Master thesis ED1-2011-128MSC 2011. 
[10] Sandnes, J. Rekstad,(2002),"A photovoltaic/thermal (PV/T) collector with a polymer absorber plate, experimental study and analytical model", Sol Energy 2002;72: PP 63-73.

[11] Zhao, X. (2003), "Investigation of a novel heat pipe collector/CHP system". Nottingham University, England, PhD 2003.

[12] Liang, R., Zhang, J., and Zhou, C., (2015), "Dynamic simulation of novel solar heating system based on hybrid photovoltaic /thermal collectors (PVT), Procedia Engineering, 121, 675-682, 2015.

[13] Sami, S. and Marin, E. (2017), "Simulation of Solar Photovoltaic, Biomass Gas Turbine and District Heating Hybrid System", International Journal of Sustainable Energy and Environmental Research, IJSEER, Vol. 6, No. 1, p 9-26, 2017.

[14] Sami, S. and Rivera, J. (2017), "A Predictive Numerical Model for Analyzing Performance of Solar Photovoltaic, Geothermal Hybrid System for Electricity Generation and District Heating", Science Journal Energy Engineering, SJEE, Volume 5, Issue 1, p 13-30, 2017.

[15] Sami, S. and Marin, E. (2017),"A Numerical Model for Predicting Performance of Solar Photovoltaic, Biomass and CHP Hybrid system for Electricity Generation", IJESRT, International Journal of Engineering Sciences \& Research Technology, Volume 4, Issue 1, p 1- 22, 2017.

[16] Good, C., Chen, J., Dai, Y and Hestnes, A.G, (2015), "Hybrid Photovoltaic-Thermal system: A Review. Energieprocedia, 70, 683-690, 2015,

[17] Faragali, H., M., Fahmy, F.H. and Hassan, M.A., (2008), "A Simulation Model for Predicting the Performance of PV/Wind- Powered Geothermal Space Heating System in Egypt", The Online Journal on Electronics and Electrical Engineering (OJEEE), Vol.2, No.4.

[18] G. Pei, Fu, H. Zhang and T.Jie“A numerical and experimental study on a heat pipe PV/T system”, Solar Energy 85(5):911-921, (2011)

[19] S. Sami and Marin, E., (2018), "Dynamic modeling and simulation of hybrid solar photovoltaic and PEMFC fuel power system", RA Journal of Applied Research, V. 4, Issue 5, pp; 1664-1683, 2018.

[20] Tardy F., Sami S. M., 2009, Thermal analysis of heat pipes during thermal storage. Applied Thermal Engineering, 29: 329-333.

[21] J. Duffie, et al., Solar Engineering of Thermal Process, Wiley, New York, 1991.

[22] Coulson J. M., Richardson J. F., Marker J. H., Backhurst J. R., (1999), Coulson \& Richardson's Chemical Engineering, Volume 1, Sixth edition Fluid Flow, Heat Transfer and Mass Transfer, Butterworth - Heinemann Publishing, Oxford, UK

[23] http://www.engineeringtoolbox.com/fouling-heat-transfer-d_1661.html

[24] Reay D.A., Kew P.A., 2006, Heat Pipes, 5th Edition, Butterworth-Heinemann publisher, Oxford, UK.

[25] Tardy,F and Sami, S.M. (2008), "An Experimental Study Determining Behaviour of Heat Pipes in Thermal Storage", International Journal of Ambient Energy, Volume 29, Number 3, 2008.

[26] A. Sweidan, N. Ghaddara, and K. Chali, (2016), "Optimized design and operation of heat-pipe photovoltaic thermal system with phase change material for thermal storage", Journal of Renewable and Sustainable Energy 8, 023501 (2016); https://doi.org/10.1063/1.4943091

[27] Sami, S. and Campoverde, C., (2018), " Dynamic Simulation and Modeling of a Novel Combined Photovoltaic -Thermal Panel Hybrid System, International Journal of Sustainable Energy and Environmental Research, V 7, No 1, Pp 1-23, 2018

[28] Zhao Xuxin, Fu Huide, Ji Jie, Sun Hongyuan, Ma Rui and Wu Qixing, (2016), “Comparative study on performances of a heat-pipe PV/T system and a heat-pipe solar water heating system"'International Journal of Green Energy, Volume 13, 2016 - Issue 3

[29] Naghavi, M.S, Silaakhori, M, and Mehrali, M.S. (2015), “Analytical thermal modeling of a heat pipe solar water heater system integrated with phase change material”, Computer Applications in Environmental Sciences and Renewable Energy, ISBN: 978-960-474-370-4, pp-197-208, 2015.

[30] Rajapakse, A, Chungpaibulpantana, S., (1994), "Dynamic simulation of a photovoltaic refrigeration system". RERIC Vol. 16 (3), 67-101.

[31] http://www.boulder.nist.gov/div838/theory/refprop/LINKING/Linking.htm\#ExcelApplications

[32] Jens Glembin, Christoph Büttner, Jan Steinweg and Gunter Rockendorf, 2015“Thermal Storage Tanks in High Efficiency Heat Pump Systems - Optimized Installation and Operation Parameters",9th International Renewable Energy Storage Conference, IRES 2015, Energy Procedia 73 (2015) 331-340

[33] S. Sami, (2018); "Modeling and Simulation of a Novel Combined Solar Photovoltaic-Thermal Panel and Heat Pump Hybrid System”, Clean Technol. 2018, 1, 89-113; doi:10.3390/cleantechnol1010007 


\section{AUTHOR'S BIOGRAPHY}

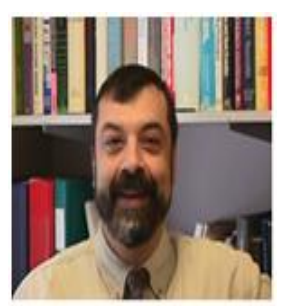

Dr. Samuel Sami, Howard is Faculty member of UCACUE, director of Research Center for Renewable Energy and Founder of Transpacific Energy, Inc. He was for 25 years Professor and Director of Research Centre for Energy Conversion, University of Moncton. He also regularly lectures in his area of expertise. He received his $\mathrm{Ph}$. D from the University of Montreal, Canada. He authored and co-authored over 200 published papers on Energy Conversion, Renewable energy and refrigerant mixtures and their use in waste heat recovery and power production, in the area of Solar PV, Thermal solar, Geothermal energy, Biomass and Thermal energy storage as well as wind turbines.

He has significant knowledge and experience in Waste Heat Recovery and renewable energy; Waste Heat Recovery technologies; WHRU; Energy Recovery Heat Exchanger; Heat Recovery Units; Heat Recovery; Energy Recovery; CHP; Combined Heat and Power; Waste Heat. Renewable energy technologies; such as thermal storage, Thermal solar, Solar PV, Biomass and geothermal and wind energy. Dr. Sami holds 14 patents in the area of refrigerant mixtures, thermodynamics, energy management and conversion, heat recovery and green energy as well as renewable energy hybrid systems.

Citation: S. Sami, (2019)"Prediction of Performance of a Novel Concept of Solar Photovoltaic-Thermal Panel and Heat Pipe Hybrid System", International Journal of Modern Studies in Mechanical Engineering, 5(1), pp. 1-26. DOI: http://dx.doi. org/10.20431/2454-9711.0501001

Copyright: () 2019 Authors, This is an open-access article distributed under the terms of the Creative Commons Attribution License, which permits unrestricted use, distribution, and reproduction in any medium, provided the original author and source are credited. 